\title{
SOURCES OF Sr AND S IN ALUMINUM-PHOSPHATE-SULFATE MINERALS IN EARLY-MIDDLE TRIASSIC SANDSTONES (IBERIAN RANGES, SPAIN) AND PALEOENVIRONMENTAL IMPLICATIONS FOR THE WEST TETHYS
}

\author{
BELÉN GALÁN-ABELLÁN, ${ }^{1}$ JACINTO ALONSO-AZCÁRATE, ${ }^{2}$ ROBERT J. NEWTON, ${ }^{3}$ SIMON H. BOTTRELL, ${ }^{3}$ \\ JOSÉ F. BARRENECHEA, ${ }^{4}$ M. ISABEL BENITO,${ }^{1}$ RAÚL DE LA HORRA, ${ }^{1}$ JOSÉ LÓPEZ-GÓMEZ, ${ }^{1}$ AND JAVIER LUQUE ${ }^{4}$ \\ ${ }^{1}$ Departamento Estratigrafia and Instituto de Geociencias (UCM, CSIC), Facultad Geología, Universidad Complutense de Madrid, ClJosé Antonio Novais 2, \\ 28040 Madrid, Spain \\ ${ }^{2}$ Facultad Ciencias del Medioambiente, Fábrica de armas, Universidad de Castilla-La Mancha, 45071 Toledo, Spain \\ ${ }^{3}$ School of Earth and Environment, University of Leeds, Woodhouse Lane, Leeds LS2 9JT, U.K. \\ ${ }^{4}$ Departamento Cristalografia y Mineralogía and Instituto de Geociencias (UCM, CSIC), Facultad Geología, Universidad Complutense de Madrid, ClJosé Antonio Novais 2, \\ 28040 Madrid, Spain \\ e-mail: galanabellan@geo.ucm.es
}

\begin{abstract}
Aluminum-phosphate-sulfate (APS) minerals, formed during early diagenesis in relation to acid meteoric waters, are the main host of $\mathrm{Sr}$ and $\mathrm{S}$ in the Early-Middle Triassic continental sandstones of the Iberian Ranges (east of the Iberian Peninsula). The sources of these elements and the effects of paleoenvironmetal changes on these sources and on the formation of APS minerals during Early-Middle Triassic times, were established on the basis of $\mathrm{Sr}$ and $\mathrm{S}$ isotopic analyses.

The $\mathrm{S}$ and $\mathrm{Sr}$ data $\left({ }^{34} \mathrm{~S}_{\mathrm{V}-\mathrm{CDT}}=+11\right.$ to $+14 \%$ and ${ }^{87} \mathrm{Sr} /{ }^{86} \mathrm{Sr}=0.7099-0.7247$, respectively) can be interpreted as resulting from mixing of different sources. Strontium was sourced from the dissolution of pre-existing minerals like K-feldspar and clay minerals inherited from the source areas, causing high radiogenic values. However, the isotopic signal must also be influenced by other sources, such as marine or volcanic aerosol that decreased the total ${ }^{87} \mathrm{Sr} /{ }^{86} \mathrm{Sr}$ ratios. Marine and volcanic aerosols were also sources of sulfur, but the $\delta^{34} \mathrm{~S}$ was lowered by dissolution of pre-existing sulfides, mainly pyrite. Pyrite dissolution and volcanic aerosols would also trigger the acid conditions required for the precipitation of APS minerals.

APS minerals in the study area are found mainly in the Cañizar Formation (Olenekian?-Aegian), which has the lowest ${ }^{87} \mathrm{Sr} /{ }^{86} \mathrm{Sr}$ ratios. The lower abundance of APS minerals in the Eslida Formation (Aegian-Pelsonian) may indicate change in the acidity of pore water towards more alkaline conditions, while the increased ${ }^{87} \mathrm{Sr}{ }^{86} \mathrm{Sr}$ ratios imply decreased $\mathrm{Sr}$ input from volcanic activity and/or marine aerosol inputs during Anisian times. Therefore, the decrease in abundance of APS minerals from the Early to Middle Triassic and the variations in the sources of $\mathrm{Sr}$ and $\mathrm{S}$ are indicative of changes in paleoenvironmental conditions during the beginning of the Triassic Period.

These changes from acid to more alkaline conditions are also coincident with the first appearance of carbonate paleosols, trace fossils, and plant fossils in the upper part of the Cañizar Formation (and more in the overlying Eslida Formation) and mark the beginning of biotic recovery in this area. The presence of APS minerals in other European basins of the Western Tethys (such as the German Basin, the Paris Basin and the southeastern France and Sardinia basins) could thus also indicate that unfavorable environmental conditions caused delay in biotic recovery in those areas. In general, the presence of APS minerals may be used as an indicator of arid, acidic conditions unfavorable to biotic colonization.
\end{abstract}

\section{INTRODUCTION}

The Early and Middle Triassic was characterized by a delay in biotic recovery after the Permian-Triassic life crisis, as a consequence of a long unfavorable environmental period (Grauvogel-Stamm and Ash 2005; Chen et al. 2007; Twitchett 2007). This began in end-Permian times, when a major rise in global temperature (Royer 2006), acid rain, oceanic transgression (Hallam and Wignall 1997), marine anoxic events (Wignall and Twitchett 2002; Woods 2005), and a higher aridity in continental environments (Smith and Botha 2005) combined to produce the most significant biotic crisis in Earth history at the Permian-Triassic boundary (PTB). Conditions adverse to life continued with several further events
(Payne et al. 2004) that delayed biotic recovery through the Early Triassic (Kozur 1998; Fraiser and Bottjer 2007). This recovery period, lasting 12 My (Kozur 1998; Chen et al. 2007), was considerably longer than those that followed other biotic crises (Corsetti et al. 2005; Twitchett 2006). Following the Permian-Triassic event, it was not until the early Anisian (approx. $247 \mathrm{Ma}$ ) that there was a general climatic change towards less arid and more seasonal-temperate conditions (Preto et al. 2010; Bourquin et al. 2011) and widespread re-establishment of life in both continental and marine environments (Grauvogel-Stamm and Ash 2005; Payne et al. 2011).

Many studies have focused on the reconstruction of events during this recovery period, mainly in marine sections, and to a lesser extent in 
continental environments (Cassinis et al. 1992; Rubidge 1995; Retallack et al. 2007; Peng et al. 2005; Botha and Smith 2006; Coney et al. 2007, Chen et al. 2007). The study of continental sections is especially difficult due to the discontinuous sedimentary record and lack of fossils.

Variation in $\mathrm{Sr}$ and $\mathrm{S}$ isotope ratios has been used to investigate environmental change throughout the Phanerozoic and specifically at the PTB in marine sedimentary rocks (Claypool et al. 1980; Dolenec et al. 2001; McArthur et al. 2001; Korte et al. 2003; Kampschulte and Strauss 2004; Newton et al. 2004; Corsetti et al. 2005; Bottrell and Newton 2006; Riccardi et al. 2006; Prokoph et al. 2008). A few isotopic studies have been made in continental sections (Strauss 1997; Maruoka et al. 2003); these point to significant changes occurring at the PTB, such as a negative excursion in $\delta^{34} \mathrm{~S}$ (Maruoka et al. 2003).

Petrography, whole-rock geochemistry, and isotopic analysis of $\mathrm{Sr}$ and $\mathrm{S}$ were performed in this study on the Triassic continental sandstones of the Iberian Ranges. These elements are mainly present in aluminiumphosphate-sulfate (APS) minerals, a group of minerals that belong to the alunite-jarosite supergroup, and they characteristically form under acid conditions (Dill 2001). In sedimentary environments, they frequently show compositions intermediate between the sulfate and phosphate end members. The formation of these phases is controlled by environmental parameters like Eh, pH, and element activities (Dill 2001; Spötl 1990; Pe-Piper and Dolansky 2005; Benito et al. 2005; Galán-Abellán et al. 2008). Therefore, the aim of this work is to establish the sources of $\mathrm{Sr}$ and $\mathrm{S}$ isotopes in Triassic continental sandstones and to look for the possible relationships between formation of APS minerals and paleoenvironmental changes during the Early-Middle Triassic. We also related these variations to sedimentological and paleontological changes that mark the beginning of the biotic recovery after the Permian-Triassic life crisis. Up to now, correlation between European basins of Western Tethys has been made using sedimentological or paleontological criteria (Díez et al. 1996; Bourquin et al. 2006; Bourquin et al. 2007; Diedrich 2009; Bourquin et al. 2011, López-Gómez et al. 2012). Here we propose that mineralogical and geochemical variations may be useful as complementary markers to establish a more accurate relationship between the environmental conditions among West Tethys Triassic basins and the beginning of the biotic recovery.

\section{GEOLOGICAL SETTING}

The study area is located in the southeastern Iberian Ranges (Spain; Fig. 1), a linear NW-SE-trending structure formed by tectonic inversion of the Iberian Basin during the Alpine Orogeny (Arche and López-Gómez 1996; Van Wees et al. 1998). At the end of the Variscan Orogeny, the early stages of the breakup of Pangea resulted in the formation of new rift systems, such as the Iberian, Pyrenean, and Catalonian basins in the Iberian plate (Fig. 2; López-Gómez and Arche 1993a; De Vicente et al. 2009; Vargas et al. 2009; Lago et al. 2012).

In the Iberian rift, isolated basins were filled by locally derived sediments during the Permian and evolved into larger and asymmetric grabens in Early Triassic times, filled by continental sediments derived from more distant sources located to the northwest (Arche and López-Gómez 1999a, 1999b; López-Gómez et al. 2002). During the Middle Triassic (Anisian) a westwards marine transgression of the Tethys Sea onlapped the continental sediments (López-Gómez et al. 1998; Arche and López-Gómez 1996, 2005).

The Permian-Triassic Boundary (PTB) is not represented in the Iberian Peninsula. There is a hiatus from Middle-Late Permian (Guapalupian-Lopingian) sediments until the middle of Lower Triassic (Olenekian) sediments (López-Gómez et al. 2002, 2012; Bourquin et al. 2011). The beginning of the Mesozoic sedimentary record is represented by two units in the southeastern Iberian Ranges: the Cañizar and Eslida formations (Early-Middle Triassic; Fig. 1C).

The Cañizar Formation consists of mainly red sandstones and lesser mudstones deposited by sandy braided rivers interbedded with minor proportion of eolian sediments, under an arid and warm climate (LópezGómez et al. 2005, 2012; Galán-Abellán 2011). It is divided into six members separated by major bounding surfaces (MBS). The lowest lies unconformably on Middle-Upper Permian sediments, and the uppermost one is unconformably onlapped by Muschelkalk facies rocks in the western area of the Iberian Ranges or by a hiatus and the Eslida Formation in its eastern part (Fig. 1C; López-Gómez and Arche 1993b). The lower part of Cañizar Formation is devoid of any fossils, however, carbonized organic matter, a palynological assemblage, incipient paleosols, and the oldest Triassic tetrapod footprints of the Iberian Peninsula occur in the uppermost part (Gand et al. 2010; López-Gómez et al. 2012). The age of the upper part is Aegian (lower Anisian) based on pollen and spore assemblages (Doubinger et al. 1990), and although the base of this unit has not been dated yet, an early Olenekian (Smithian) age has been inferred based on correlations with equivalent sediments in the Catalonian Ranges and other European basins (Dinarès-Turrel et al. 2005; Bourquin et al. 2011; López-Gómez et al. 2012).

The Eslida Formation is present only in the easternmost part of the Iberian Basin. This is due to the higher subsidence rate of the area where the NW-SE-trending Iberian rift of converged with another rift system of NE-SW direction during Anisian times (Fig. 2; Arche and López-Gómez 1996). It consists of sandstones and interbedded mudstones deposited by sandy braided rivers and also meandering rivers with wide floodplains, under a temperate and more humid climate than in the Cañizar Formation. The upper boundary is transitional with sediments of the Marines Formation (Röt facies, which is also transitional to the Muschelkalk facies), and the lower one is mainly represented by a hiatus overlying the Cañizar Formation (Fig. 1C). Biodiversity is enhanced in the Eslida Formation (Fig. 3) with the presence of tetrapod traces and plant and invertebrate fossils (Bèthoux et al. 2009; Gand et al. 2010; Galán-Abellán 2011). It is also divided into six members whose ages range from Pelsonian (middle Anisian) for the upper part to Bithynian-Aegian (early Anisian) for the lowest members (Boulouard and Viallard 1982; Doubinger et al. 1990; López-Gómez et al. 2012). The lowest members are represented only in the depocenter of the basin (Fig. 3; Arche and LópezGómez 1999a).

\section{METHODS}

\section{Sampling}

A total of 67 samples were collected from six different sections (Fig. 1B) Río Mayor (8 samples), Talayuelas (8), Gátova (14), Montán (14), Alfondeguilla (15), and Benicassim (8), and analyzed using various analytical techniques, as described below.

Sampling was as uniform as possible along the sections; we tried to collect samples from all subunits, in order to compare chemical and mineralogical variations between units and subunits. However, this was not always possible. In the Cañizar Formation, the uppermost member is often weathered, and it commonly ends with a ferruginous crust. Furthermore, the base of the Cañizar Formation begins with conglomerates and coarse sandstones. In the case of the Eslida Formation not all subunits are represented in the study area, inasmuch as this depends on the subsidence evolution, as explained in section 2 (Fig. 3).

The samples are medium- and fine-grained sandstones, siltstones, and mudstones, collected avoiding any weathered surface. Petrographic analysis was performed in medium- and fine-grained sandstones, whereas geochemical analyses were performed mainly on siltstones, mudstones, and, to a minor extent, some fine-grained sandstones.

\section{Petrographic and Mineralogical Study}

Thin sections were studied by conventional transmitted-light microscopy, identifying the various mineral phases and cements and performing 


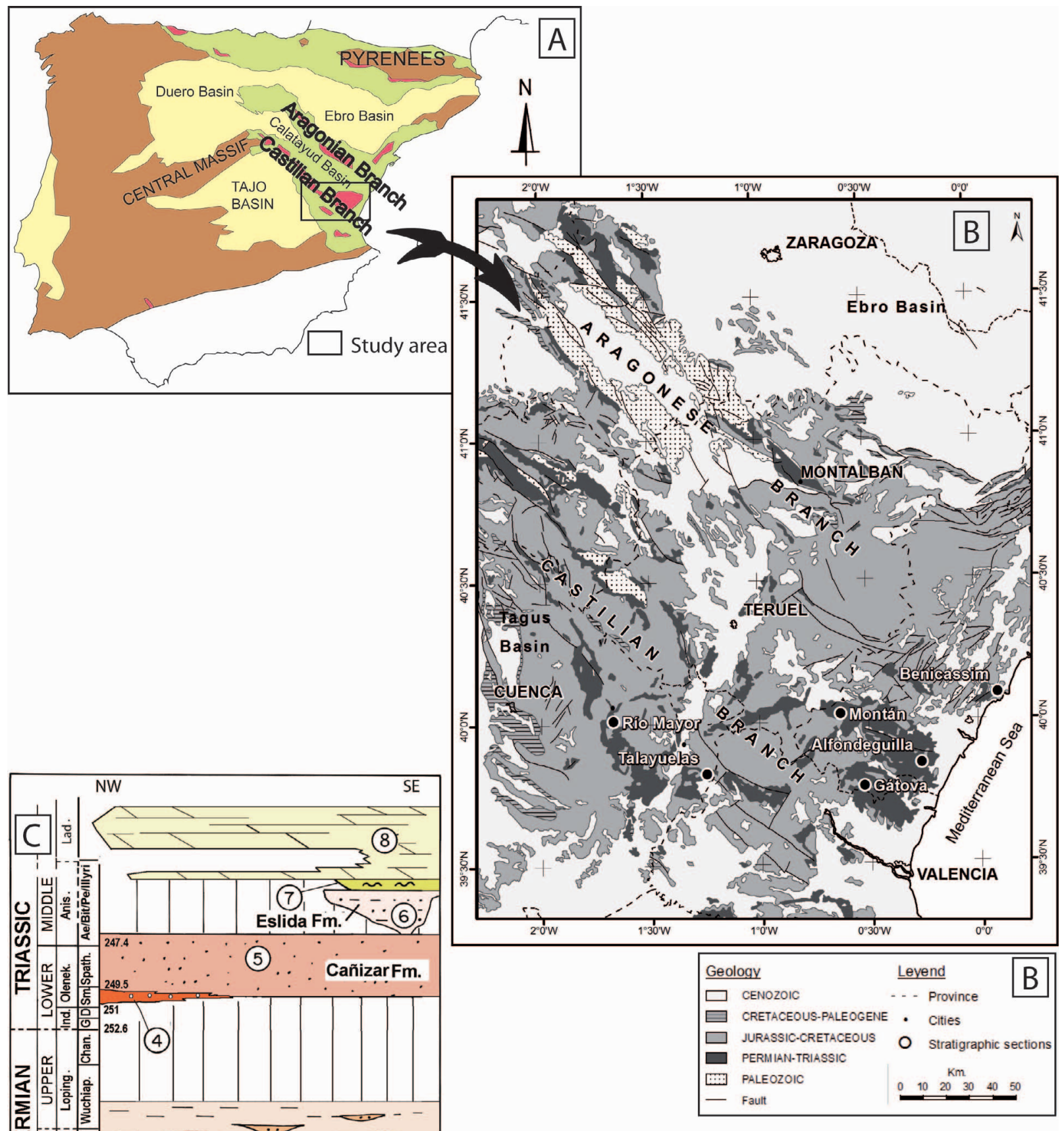




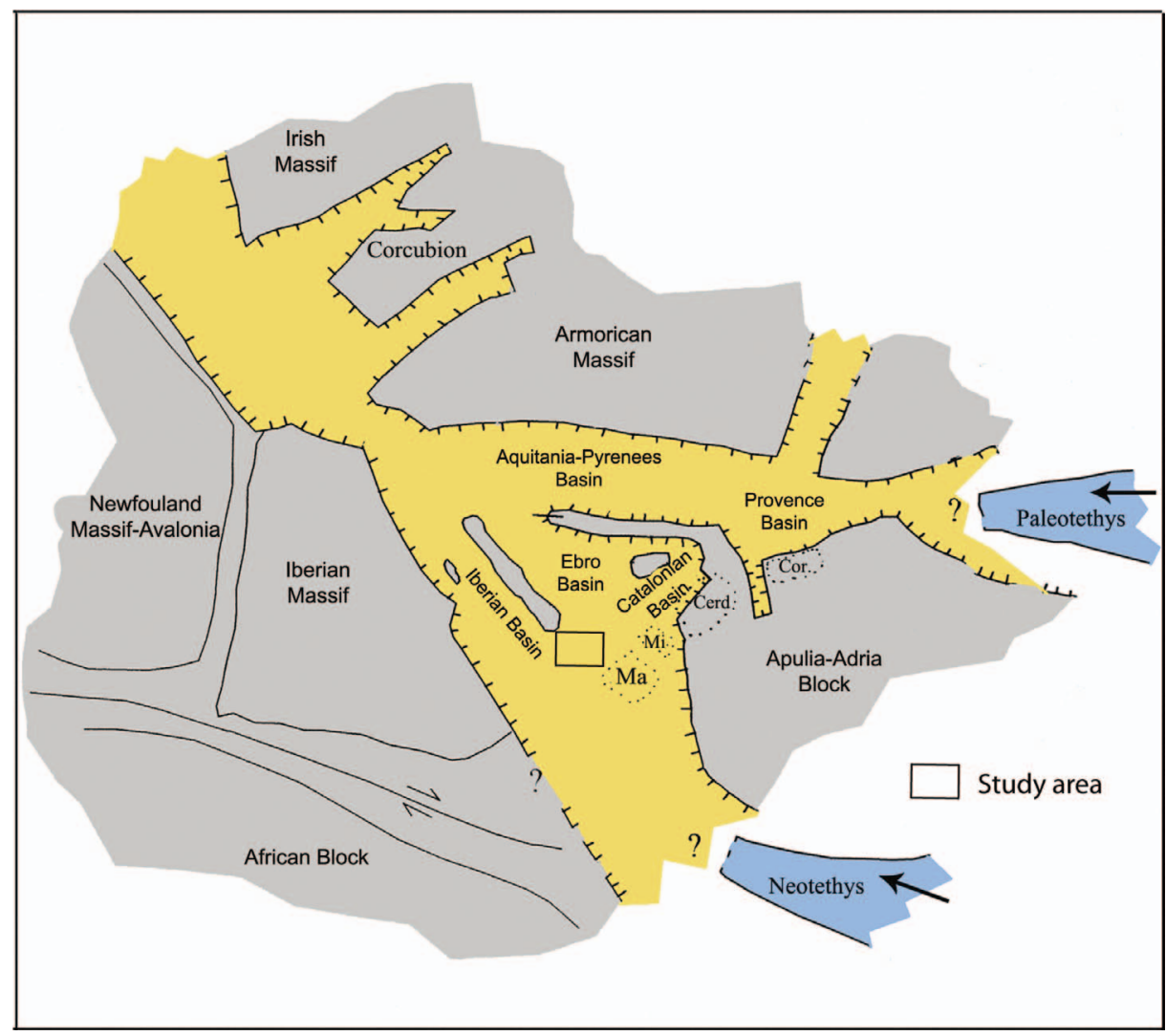

FIG. 2.-Scheme of the main rift systems in the Iberian plate and the west Tethys area during Lower Triassic. (Ma, Majorca; Mi, Minorca; Cer, Sardinia; Cor, Corsica). (Modified from Lago et al. 2012). The black square marks the study area. a visual estimation of the main components for the petrographic characterization of sandstones. This study led us to establish the textural relationships between grains and cements, and the timing of formation of authigenic minerals and cement.

Mineral compositions were analyzed on polished thin sections of sandstones and siltstones by electron microprobe (EMPA) at the Centro Nacional de Microscopía Electronica of the Complutense University (Madrid, Spain). A JEOL JZA-8900 M electron microprobe equipped with five wavelength-dispersive spectrometers was used with a beam diameter of $5 \mu \mathrm{m}$. The analytical conditions were $15 \mathrm{kV}$, an electron beam of current of $20 \mathrm{nA}$, and $10 \mathrm{~s}$ of elemental counting times. Analyses were corrected for electronic interactions using a ZAF procedure. In addition, mapping of $200 \times 200$ points with an interval measure point of $0.20 \mu \mathrm{m}$ for each element ( $\mathrm{Sr}, \mathrm{S}, \mathrm{P}, \mathrm{Ca}, \mathrm{Na}, \mathrm{La}, \mathrm{Ce}$, and $\mathrm{Fe}$ ) were performed in some APS minerals. The structural formulae of APS minerals have been calculated on the basis of 11 oxygen atoms p.f.u.

\section{X-Ray Diffraction (XRD)}

XRD was used to characterize bulk-rock and clay mineralogy in mudstones. Initially samples were ground in an agate mortar and sieved to $<53 \mu \mathrm{m}$. Clay minerals were identified in oriented aggregates of the $<2 \mu \mathrm{m}$ fraction that was separated from the sample by suspension in distilled water. Air-dried oriented aggregates were then solvated with ethylene glycol for $24 \mathrm{~h}$ and heated to $550^{\circ} \mathrm{C}$ for 2 hours to aid in identification of minerals of the smectite, vermiculite, and chlorite groups. The samples were analyzed on a Siemens D500 diffractometer at the Crystallography and Mineralogy Department of Complutense University (Madrid, Spain) using $\mathrm{Cu}-\mathrm{K} \alpha$ $40 \mathrm{kV}$ and $30 \mathrm{~mA}$. The scan range was $2-65^{\circ} 2 \theta$ for the study of the bulk mineralogy and $2-35^{\circ} 2 \theta$ for orientated aggregates at a rate of $1.2^{\circ} 2 \theta / \mathrm{min}$.

\section{Whole-Rock Geochemistry}

Samples of mudstones, siltstones, and some fine-grained sandstones were milled in an agate mortar and sieved to $<53 \mu \mathrm{m}$. Whole-rock chemical analyses were performed in the Faculty of Environmental Science of Castilla-La Mancha University (Toledo, Spain) using an ICPOESI ICAP 6500 Thermo Electron for major elements, and an ICP-MS X Series II Thermo Electron for minor and trace elements. Solutions were prepared fluxing $0.25 \mathrm{~g}$ of each sample and $0.50 \mathrm{~g}$ of lithium metaborate, dissolved in $100 \mathrm{ml}$ of $\mathrm{HNO}_{3} 1 \mathrm{~N}$ and three drops of HF. Five USGS standards (GPS-2: Silver Plume Granodiorite; BCR-2: Columbia River Basalt; AGV-2: Guano Valley Andesite; SDC-1: Analyzed Mica Schist; SGR-1b: Green River Shale) were used for external calibration.

\section{Isotope Geochemistry}

To establish $\mathrm{Sr}$ and $\mathrm{S}$ sources, ${ }^{87} \mathrm{Sr} /{ }^{86} \mathrm{Sr}$ and $\delta^{34} \mathrm{~S}$ isotopic studies in whole rock were carried out in mudstones and siltstones and in some fine-grained sandstones. ${ }^{87} \mathrm{Sr} /{ }^{86} \mathrm{Sr}$ isotopic ratios were determined at the Geochronology

$\leftarrow$

FIG. 1.-A) Map of the main geological structures of Iberian Peninsula showing the location of the studied area, in the SE Castilian Branch of the Iberian Ranges. B) Detailed geological map of the studied area and location of the six studied sections. C) Chronostratigraphic scheme of the Permian and Triassic units and their stratigraphic relationship. The units studied in this work are the Cañizar and the Eslida formations (modified after López-Gómez and Arche 1993a). 


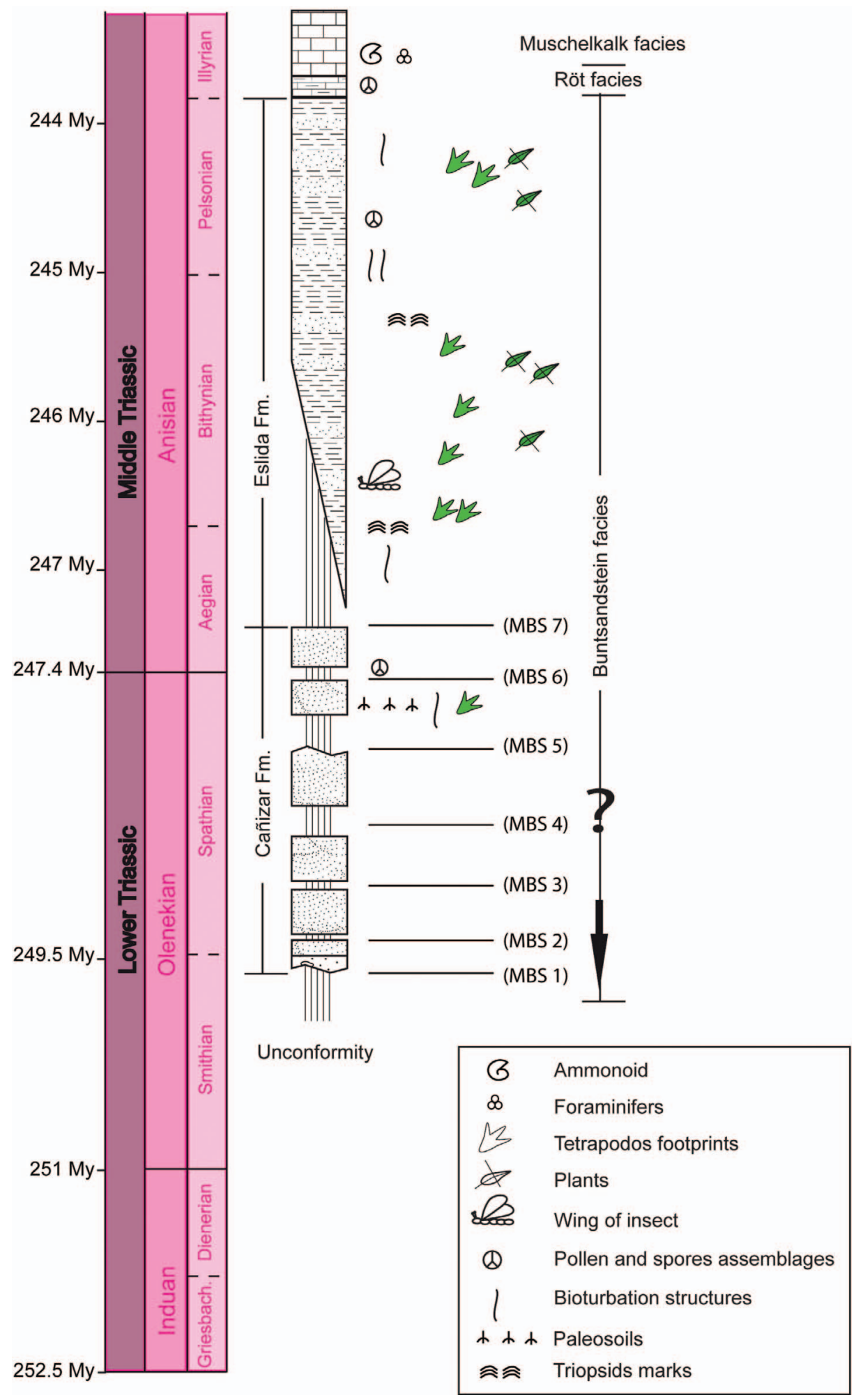

FIG. 3.-Detailed chronostratigraphic scheme of the Cañizar and Eslida formations, and their fossil content. Note that the first fossil records occur above MBS- 5 and the higher biotic abundance and diversity is in the Eslida Formation. and Isotope Geochemistry Centre of the Complutense University (Madrid, Spain). $0.2 \mathrm{~g}$ of each sample was dissolved in $5 \mathrm{ml}$ of $\mathrm{HF}$ and $2 \mathrm{ml}$ of $\mathrm{HNO}_{3}$ (Merk-Suprapur), then heated for 48 hours at $120^{\circ} \mathrm{C}$ in Teflon digestion bombs and, finally, dried in a fume cupboard for $12 \mathrm{~h}$. After this procedure, $2 \mathrm{ml}$ of $\mathrm{HNO}_{3}$ were added to dry samples to dissolve any possible fluoride formed and dried again. Finally, $6 \mathrm{ml}$ of $\mathrm{HCl} 6 \mathrm{~N}$ were added and heated at $120^{\circ} \mathrm{C}$ for $12 \mathrm{~h}$. The residue was centrifuged $10 \mathrm{~min}$ at $4000 \mathrm{rpm}$, and supernatant was loaded onto chromatography columns to separate $\mathrm{Sr}$ using Dowex $A G-50 \times 12$ cation exchange resin. ${ }^{87} \mathrm{Sr} /{ }^{86} \mathrm{Sr}$ ratios values were measured on a Multicollector VG Sector 54 Mass Spectrometer (TIMS). Analytical error throughout as two standard deviations is $0.01 \%$. All data were corrected to the NBS-987 isotopic standard.

The $\delta^{34} \mathrm{~S}$ isotopic analyses were performed at the School of Earth and Environment of Leeds University (UK) using an Isoprime mass 


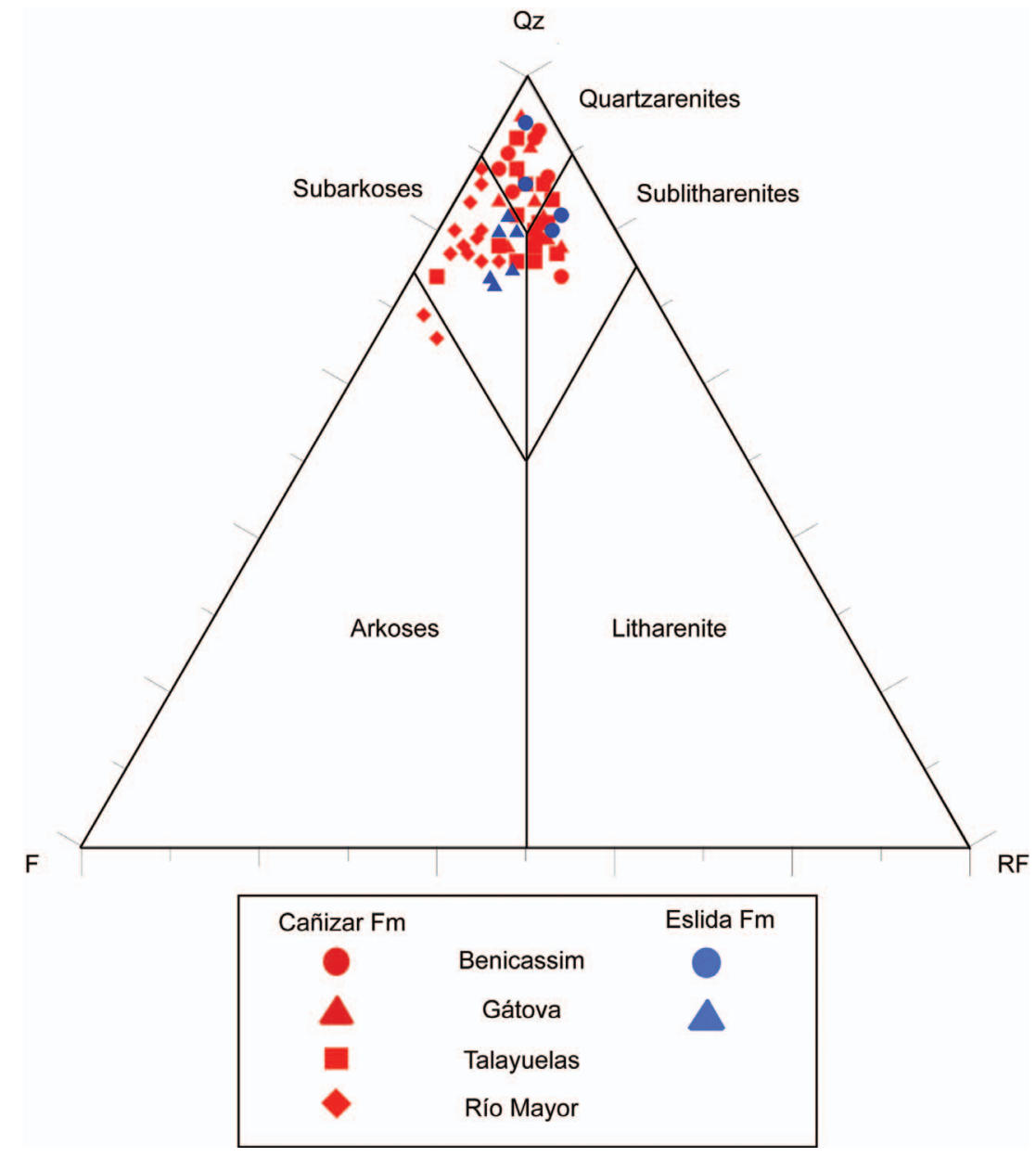

FIG. 4.-Plot of sandstone compositions for Cañizar and Eslida formations in the quartz-feldspars-rock fragments diagram (Folk 1974). The diagram shows that there are no significant differences in sandstone compositions from Eslida and Cañizar formations or between the different studied sections.

spectrometer coupled to a Eurovector Elemental Analyser. Samples were milled in an agate mortar, and the $<2 \mu \mathrm{m}$ fraction was separated from an aqueous suspension. The samples were pre-treated with $\mathrm{NaClO}$ to eliminate any sulfide present.

Approximately $10 \mathrm{mg}$ of each sample (both treated and untreated with $\mathrm{NaClO}$ ) were weighed out in tin capsules and put in the analyzer. The $\mathrm{S}$ of each sample was converted to $\mathrm{SO}_{2}$ by flash combustion at $1020^{\circ} \mathrm{C}$ in the presence of a pulse of oxygen injected into a stream of helium. The resulting gases were passed through hot copper wires to remove excess oxygen, and through magnesium perchlorate to remove water. The $\mathrm{SO}_{2}$ was separated from other impurities using a chromatographic column and a helium carrier gas. The results were calibrated using two interlaboratory reference materials: chalcopyrite $\left(\mathrm{CP}-1=-4.56 \%{ }_{\mathrm{v}}\right.$-CDT $)$ and barium sulfate (SWS-3a $=+20.3 \%$ ov-CDT) relative to the Vienna-Canyon Diablo Troilite (V-CDT) standard. Reproducibility of standard materials analysis is better than $0.3 \%$ (1 standard deviation).

\section{RESULTS}

\section{Petrography and Mineralogy}

The Cañizar and Eslida formations are both composed mainly of sandstones and mudstones. Sandstones correspond to subarkoses (with minor amounts of quartz arenites, arkoses, and sublitharenites) (Fig. 4) with quartz, K-feldspar, micas, and lithic fragments (mainly metamorphic and igneous) as principal components (Fig. 5A, B). Tourmaline, zircon, monazite, apatite, xenotime, rutile, hematite, and aluminium-phosphatesulfate minerals occur as accessories. There are no significant differences in the bulk mineralogical composition of sandstones between the Cañizar and Eslida formations (Fig. 4). The main difference between the two formations is the local occurrence of carbonate concretions in some paleosols in the Eslida Formation (Fig. 5C), whereas the Cañizar Formation is devoid of carbonate (Fig. 6). Clay minerals in the sandstones and mudstones are mainly illite, with minor amounts of kaolinite, which is more prevalent in the eastern sections (Fig. 6).

The framework grains of the sandstones in both formations are coated by Fe-oxyhydroxide cement (Fig. 5D). Some feldspar grains are partially or totally altered to illite and/or kaolinite (Fig. 5E, F), a feature that is more frequently observed in samples from the easternmost sections (Fig 6). Occasionally, after feldspar dissolution, the secondary porosity was filled by illite and kaolinite, which preserved the sub-euhedral morphology of the feldspar crystals (Fig. 7A). Detrital mica plates may be also partially replaced by kaolinite, which show fan-shaped edges (Fig. 7B). Among other accessory minerals are APS minerals and detrital phosphates (apatite, monazite, and xenotime; Table 1A) occasionally corroded (Fig. 7C).

APS minerals occur as small $(2-3 \mu \mathrm{m})$ disseminated pseudocubic crystals (Fig. 7D) and as polycrystalline aggregates $(100-200 \mu \mathrm{m}$ in length) replacing lithic fragments (Fig. 7E, F). The original texture of some lithic fragments, which are replaced by APS, is still observable (Fig. 7F). Anhedral APS crystals occur in the cores of these aggregates, 

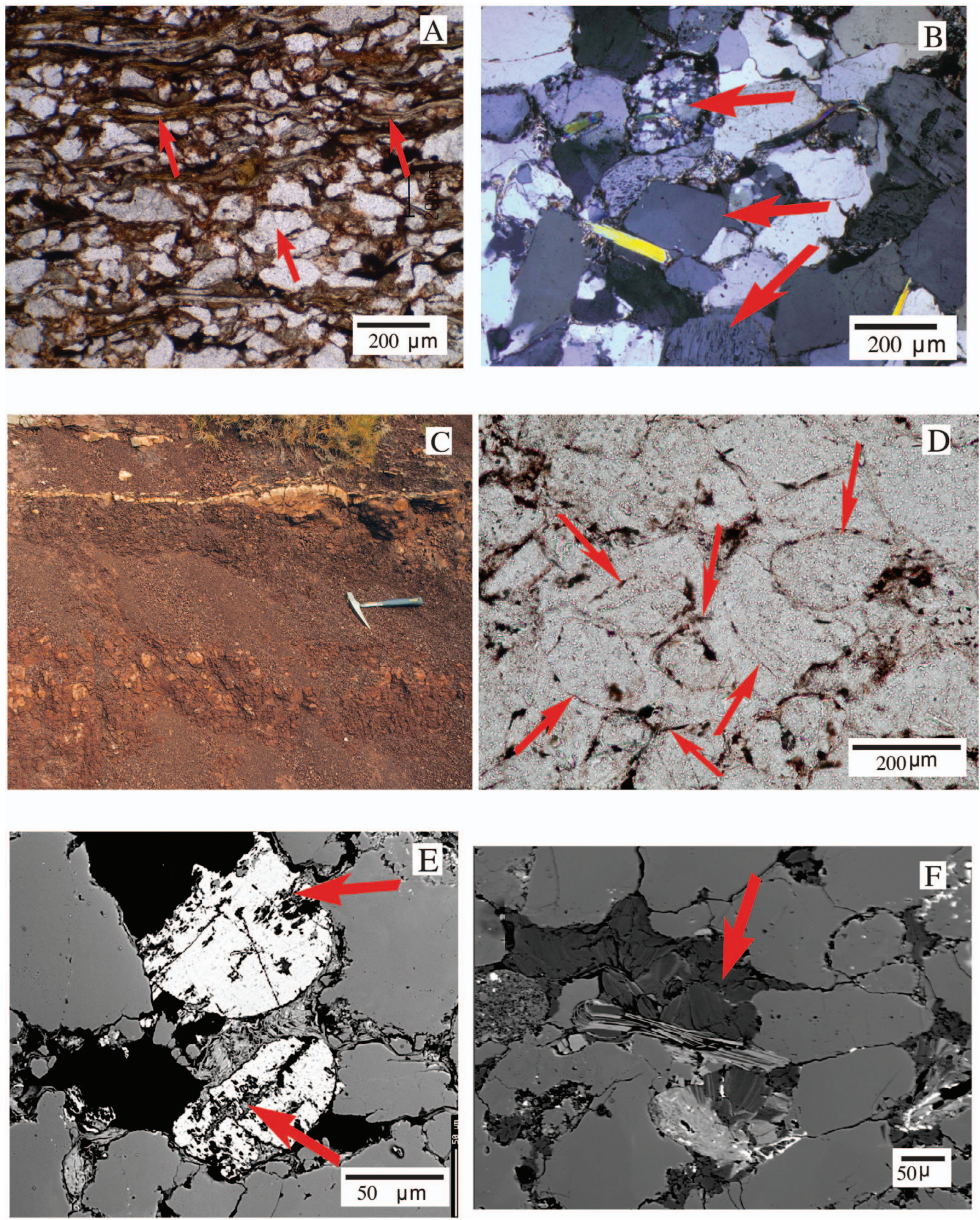


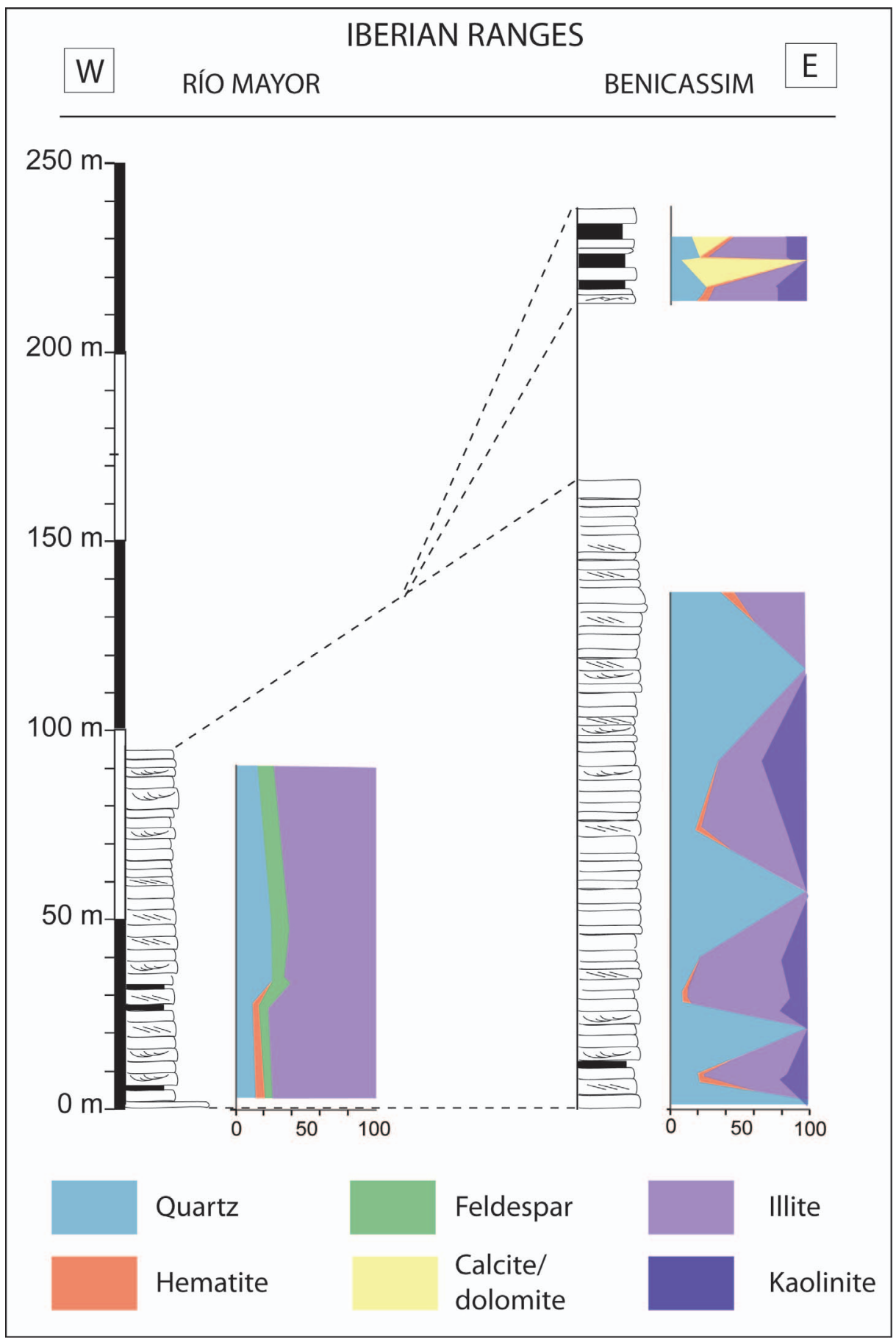

Fig. 6.-XRD patterns of the eastern (Río Mayor) and the western (Benicassim) sections. The main difference within the Cañizar Formation is the absence of feldspars and the presence of kaolinite in the Benicassim section with respect to the Río Mayor section. Carbonates (calcite and dolomite) occur in samples from the Eslida Formation, but they are absent from the Cañizar Formation.

$\leftarrow$

FIG. 5.-A, B) Thin-section photomicrograph of the studied sandstones under transmitted and polarized light. The main detrital components, marked with red arrows, are quartz, micas, feldspars, and minor lithic fragments. C) Moderate to well-developed paleosols of the Eslida Formation showing shallow ( $<1 \mathrm{~m}$ deep) nodular and petrocalcic calcareous horizons with little lateral extension. D) Fe-oxi-hydroxides cement surrounding detrital grains (red arrows). These cements form Fe-oxides coatings around detrital quartz and they allow differentiation of quartz grains from syntaxial quartz cements. E) Two feldspar crystals (light grey) partially altered to illite (red arrows) (BSEM image). F) Detrital grain completely replaced by kaolinite. The space occupied by kaolinite has a size similar to that of the surrounding grains (BSEM image). 

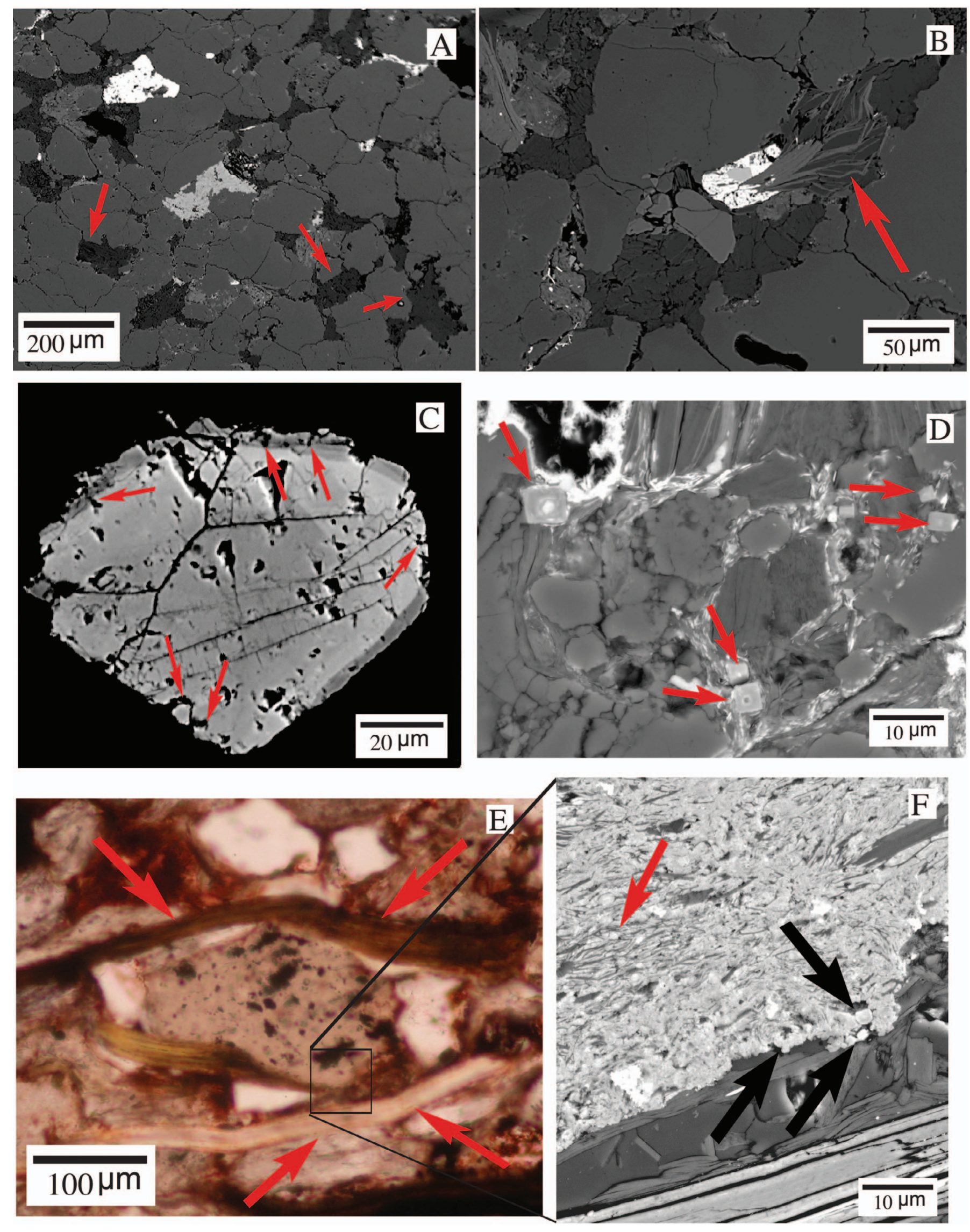
TABLE 1A.-EMPA analyses of some detritial phosphates like apatite, monazite, and xenotime.

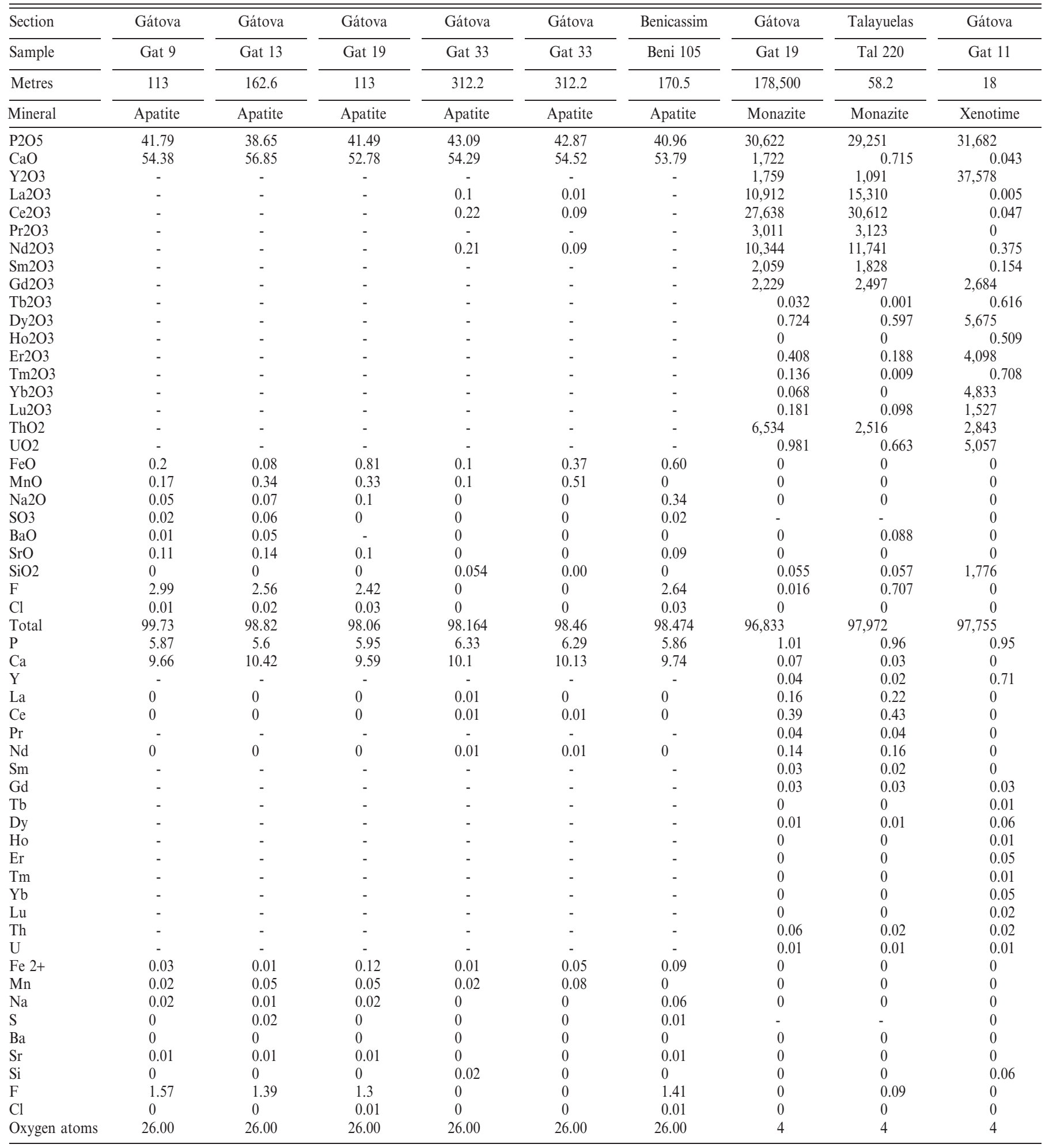

FIG. 7.-A) Kaolinite aggregates that formed after feldspar dissolution. Note the similar size that kaolinite aggregates display compared to the surrounding grains and the subidiomorphic shape of many of them, resembling that of feldspar grains (red arrows, BSEM image). B) Kaolinite (dark gray) partially replacing a detrital mica plate (light gray), developing a fan morphology (red arrow) (BSEM image). C) BSEM image of a corroded monazite grain showing corrosion embayments at the edges (red arrows). D) Isolated APS crystals (red arrows) surrounded by quartz and clay minerals. E) Polycrystalline aggregate of APS minerals replacing a lithic fragment. Note that detrital micas are deformed around the fragment due to mechanical compaction (red arrows) (transmitted-light microscopy image). F) The elongated morphology of replaced micas in the aggregate core can be still recognized (red arrows). At the edge of the lithic fragment, APS developed subidiomorphic pseudocubic crystals (black arrows) (detail of Part E, BSEM image). 
whereas subidiomorphic crystals are found in the outer part of the aggregates (Fig. 7F). These aggregates are usually associated with Feoxides (Fig. 8A) and with kaolinite that precipitated after feldspar alteration (Fig. 8B, C). Syntaxial quartz cement precipitated in the remaining porosity and postdates formation of APS minerals and kaolinite (Fig. 8E).

Mechanical compaction affects mainly detrital micas and lithic fragments (Fig. 8D). However, the lithic fragments that are replaced by APS are commonly less deformed (Fig. 8D) than nonreplaced fragments, since APS minerals are more resistant to mechanical compaction. Moreover, mechanical compaction caused deformation of detrital micas and/or authigenic clay minerals around APS aggregates (Figs. 7E, 8C).

There are no differences in APS composition determined by EMPA between samples from the Cañizar and Eslida formations. The analyzed minerals are phosphate-sulfates $(\mathrm{P}: \mathrm{S}$ ratio $=3: 1)$ with $\mathrm{Sr}$ and minor amounts of $\mathrm{Ca}$ (Table 1B). Their average chemical composition is: $\left((\mathrm{REEs})_{0.09} \mathrm{~K}_{0.01} \mathrm{Ba}_{0.01} \mathrm{Ca}_{0.27} \mathrm{Sr}_{0,51}\right) \mathrm{Al}_{3.09}\left(\mathrm{P}_{1.53} \mathrm{~S}_{0.43} \mathrm{As}_{0.01} \mathrm{Si}_{0.05}\right)_{2} \mathrm{O}_{8}$ $(\mathrm{OH})_{6}$. This composition is intermediate between the end terms woodhouseite-svanbergite-crandallite-goyazite. Nevertheless, detailed BSEM images of single APS crystals do show compositional variations. They are formed by irregular cores surrounded by idiomorphic and zoned rims probably resulting from different growth stages (Fig. 8E). The elemental mapping of APS aggregates (Fig. 8F) reveals differences in the location of the areas of highest concentration for REEs, Ca, Sr, P, and $\mathrm{S}$. The highest concentrations of $\mathrm{P}$ and $\mathrm{Sr}$ are coincident, as well as those of $\mathrm{La}$ and $\mathrm{Ce}$. However, highest $\mathrm{Ca}$ and $\mathrm{Sr}$ contents do not exactly overlap.

\section{Whole-Rock Analysis}

Figure 9 shows the whole-rock concentrations of $\mathrm{Sr}, \mathrm{P}, \mathrm{La}$, and $\mathrm{Ce}$ from five of the studied sections. These concentrations was normalized to Si to eliminate any compositional bias due to the quartz content in samples with different grain sizes (between 0.002 and $0.5 \mathrm{~mm}$ ). However, there is no significant bias due to the quartz content of the samples because the trend for normalized and non-normalized samples is the same. The highest concentrations of $\mathrm{Sr}$ are detected in samples from the basal part of the Cañizar Formation, and this concentration decreases towards the Eslida Formation.

Plotting of $\mathrm{P}$ vs. Sr concentration shows two different populations (Fig. 10A). One group corresponds to the Cañizar samples, and the other group includes the samples from the Eslida Formation. In the Cañizar Formation there is a very good positive correlation between both elements (Fig. 10B) with $r^{2}$ values $=0.81-0.99$ in most sections and lower $r^{2}$ in the Gátova and Alfondeguilla sections. However, in the Eslida Formation there is a poor correlation between $\mathrm{P}$ and $\mathrm{Sr}$ (Fig. 10B), probably due to the occurrence of a higher proportion of detrital phosphates, as discussed below.

\section{Sr Isotopes}

There is an increase in the ${ }^{87} \mathrm{Sr} /{ }^{86} \mathrm{Sr}$ ratios upwards in each section (Figs. 9, 11; Table 2); in the Cañizar Formation the ${ }^{87} \mathrm{Sr} /{ }^{86} \mathrm{Sr}$ values range from 0.7105 to 0.7158 , whereas in the Eslida Formation values vary from 0.7127 to 0.7422 . Moreover, there is a negative correlation between ${ }^{87} \mathrm{Sr} /{ }^{86} \mathrm{Sr}$ and the $\mathrm{Sr}$ content in most of the sections in both the Cañizar and Eslida formations (Fig. 11).

\section{S Isotopes}

Table 3 shows the values of $\delta^{34} \mathrm{~S}$ obtained in samples treated and untreated with $\mathrm{NaClO}$. There are no systematic differences between them. The $\delta^{34} \mathrm{~S}$ values show a relatively narrow range between $+11 \%$ and $+14 \%$. There are no remarkable differences between the $\delta^{34} \mathrm{~S}$ values from the Cañizar and Eslida formations.

\section{DISCUSSION}

\section{Textural Features of APS Minerals}

Petrological and mineralogical results show no significant differences between the Cañizar and Eslida formations, other than the absence of carbonates in the Cañizar Formation. The most remarkable feature of these units is the presence of APS minerals, as was first reported in this area by Benito et al. (2005).

The textural relationship between APS intergrown with kaolinite (Fig. 8B) indicates that both phases probably formed during the same stage of diagenesis and under similar diagenetic conditions. The fan-shape morphology of kaolinite points to an early diagenetic origin, when the sediment was not completely compacted and fans could be developed. Eodiagenetic to early mesodiagenetic kaolinite has previously been reported in coeval and similar fluvial deposits in other areas of the Iberian Basin (Arribas 1987; De la Cruz et al. 1987; Martín-Martín et al. 2007). Thus, data from textural relationships and previous studies indicate that kaolinite and APS likely precipitated during early diagenesis.

Another feature, which supports this hypothesis, is that APS minerals replacing lithic fragments apparently prevented mechanical compaction (Fig. 7E), while nonreplaced fragments are frequently deformed (Fig. 8D). Moreover, minerals surrounding the APS aggregates (micas or authigenic illite and kaolinite) are deformed around them (Figs. 7E, 8C), suggesting that APS formation occurred during the early stages of mechanical compaction and before the porosity was filled by quartz cement (Fig. 8E).

Moreover, the paragenesis found in this study is consistent with the early formation of diagenetic APS minerals in sandstones described by Spötl (1990) and Pe-Piper and Dolansky (2005), who reported similar conditions of formation, that is, low-temperature, early diagenetic conditions. Finally, there is no field evidence of generalized hydrothermal activity that could have affected the study area (Benito et al. 2005, 2011); only the Alfondeguilla section shows any evidence, in the form of late hydrothermal veins of quartz, crosscutting sandstone horizons that are locally recrystallized.

\section{APS Origin and Conditions of Formation}

The aluminum-sulfate-phosphate minerals found in the Iberian Triassic sandstones are composed mainly of $\mathrm{Al}, \mathrm{Ca}, \mathrm{P}, \mathrm{Sr}$, and $\mathrm{S}$, with minor amounts of REEs like La, Ce, and Nd (Table 1B). Aluminum may have been supplied by the observed dissolution of micas and feldspars

FIG. 8.-A) Polycrystalline APS aggregate (light gray) intergrowth with pseudocubic Fe-oxihydroxides (white) (red arrows). Fe-oxihydroxides could correspond to pseudomorphs after pyrite (BSEM image). B) APS crystals (light grey) intergrown with kaolinite (dark grey). Notice that kaolinite is surrounding APS minerals and APS are also surrounding kaolinite (red arrows). C) Polycrystalline APS aggregate (light gray) surrounded by authigenic clay minerals (dark gray). Notice that clays are deformed and adapted around the APS aggregate shape (red arrows) due to the mechanical compaction (BSEM image). D) BSEM image of a Cañizar Formation thin section. The image shows some detrital micas and lithic fragments deformed by mechanical compaction (red arrows). In contrast, the lithic fragment replaced by APS minerals (white color) is not deformed even though it is surrounded by quartz grains. E) Polycrystalline APS aggregate surrounded by quartz and kaolinite (to the right). Red arrows indicate quartz cement precipitated after APS crystals, filling remaining porosity (BSEM image). F) Elemental mapping of Sr, S, Ca, P, La, and Ce of an APS aggregate. Color scale represents the concentration (counts per second) of each element. Dark blue corresponds to 0. Purple color corresponds to maximum elemental concentrations. Scale bar represents $4 \mu \mathrm{m}$. 


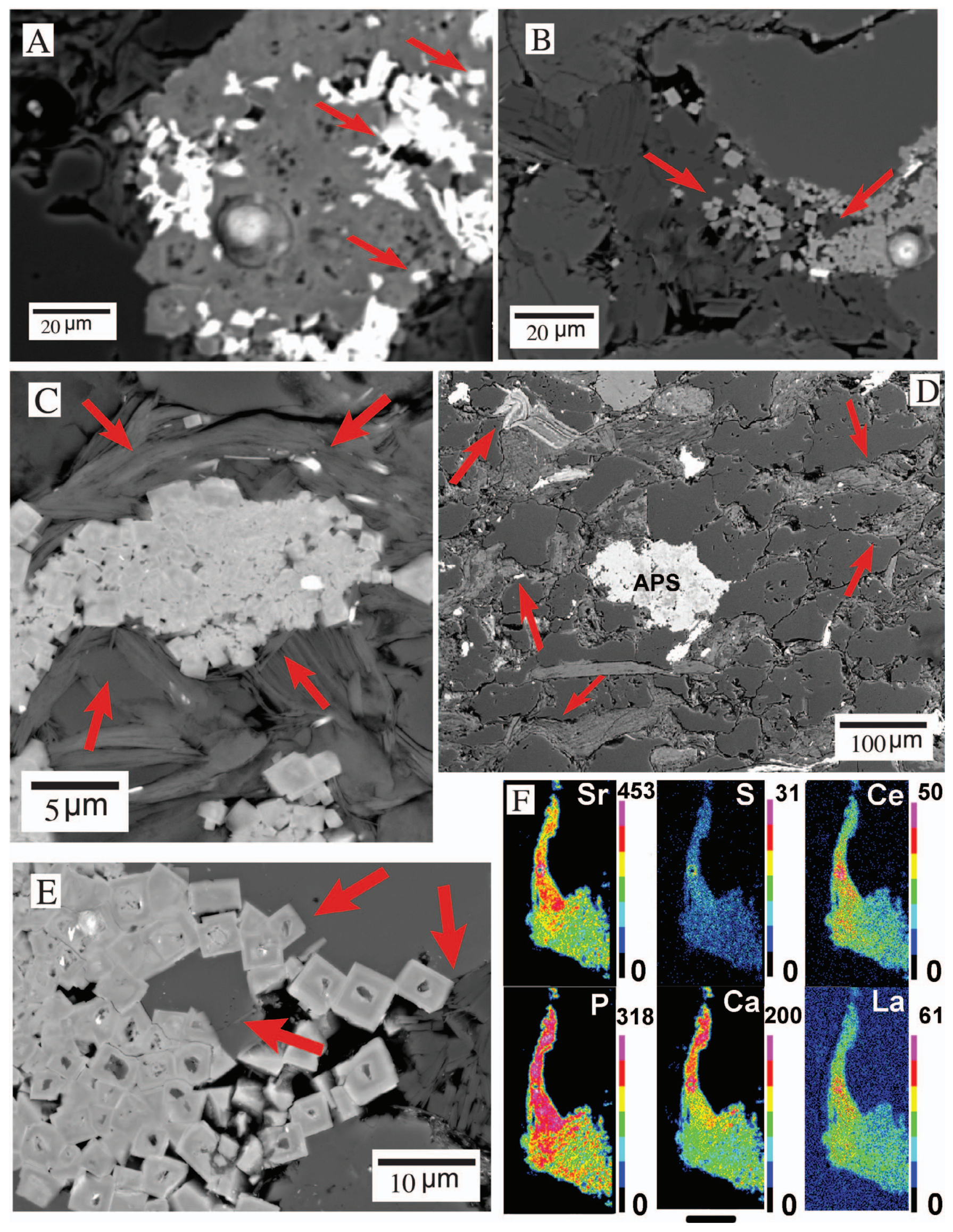


TABLE 1B.-EMPA analyses of APS minerals of samples from different sections.

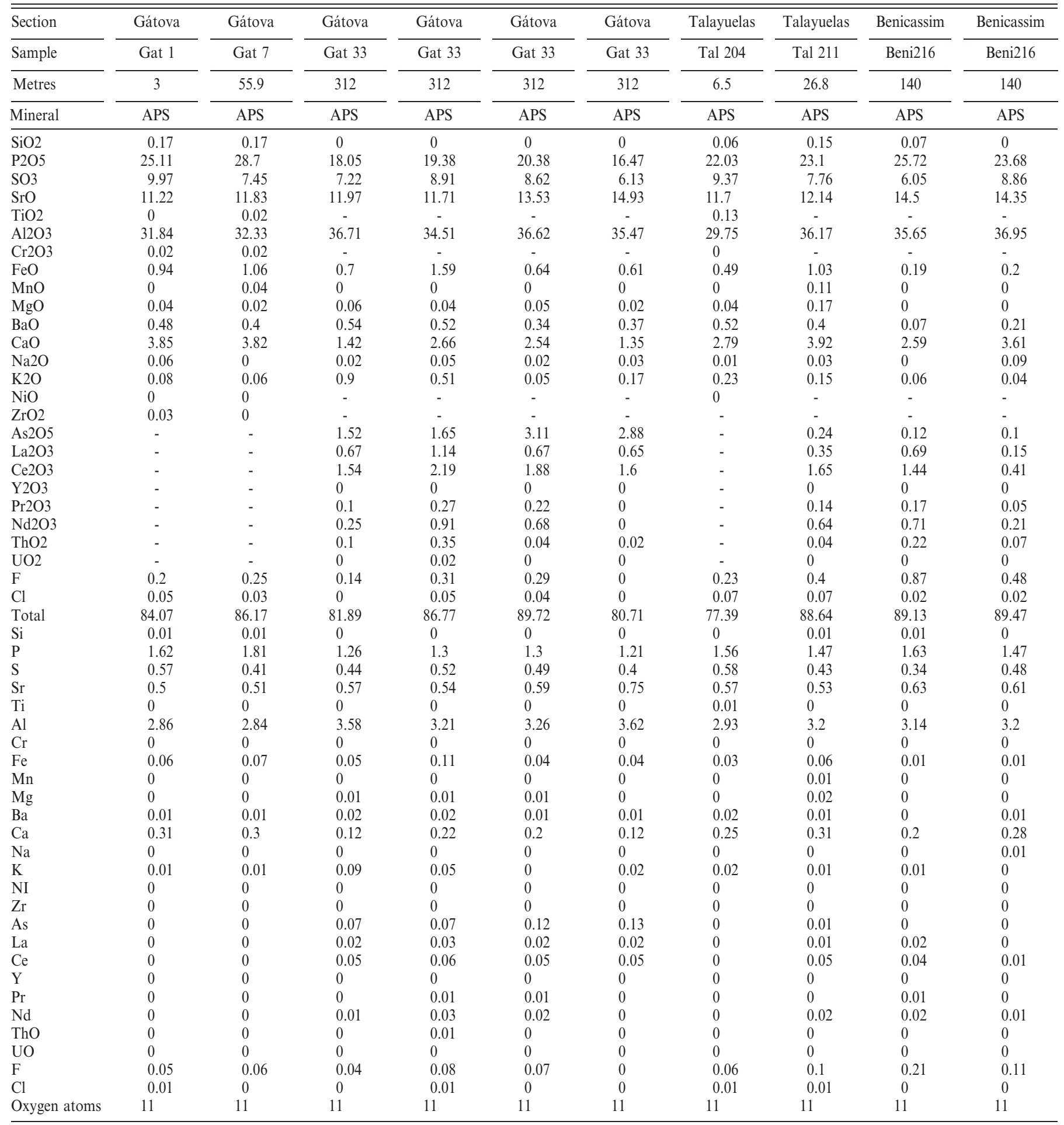

replaced by clay minerals (Figs. 5E, 7B). Carbonate dissolution does not appear to be a significant source for $\mathrm{Ca}$, because there are no carbonates in the Cañizar Formation (Fig. 6), where APS are more abundant, and only a few thin and isolated paleosols with some carbonates occur in the Eslida Formation (Fig. 5C). However, the dissolution of preexisting detrital phosphates (apatite, monazite, xenotime), as inferred from corroded grains (Fig. 7C), would be the most likely source for $\mathrm{Ca}$ and also for other elements (P, La, Ce, and Nd; Table 1A). Dissolution of detrital phosphates, feldspars, and clay minerals is more readily achieved under acidic conditions (Guidry and Mackenzie 2003), consistent with formation conditions of APS and kaolinite. 

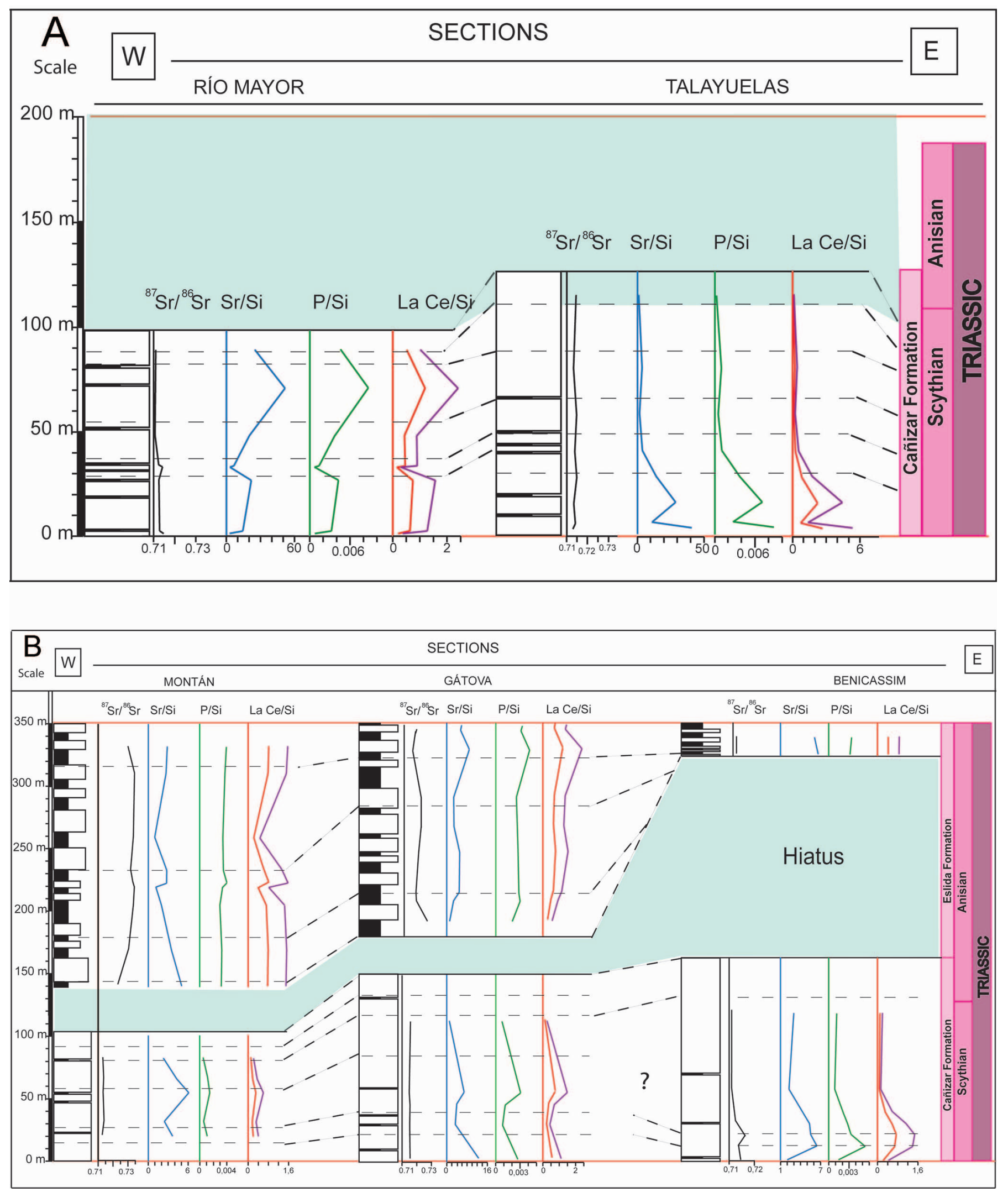

FIG. 9.-Variations of $\mathrm{Sr}, \mathrm{P}, \mathrm{La}$, and $\mathrm{Ce}$ concentrations, and ${ }^{87} \mathrm{Sr} /{ }^{86} \mathrm{Sr}$ ratios, along the studied units in different sections. The scale for element concentration is not the same for all elements and sections, due to the differences in the magnitude order of element concentrations. The $\mathrm{Sr}$ concentration and the ${ }^{87} \mathrm{Sr} /{ }^{86} \mathrm{Sr}$ ratios are higher in the Cañizar Formation than in the Eslida Formation. 

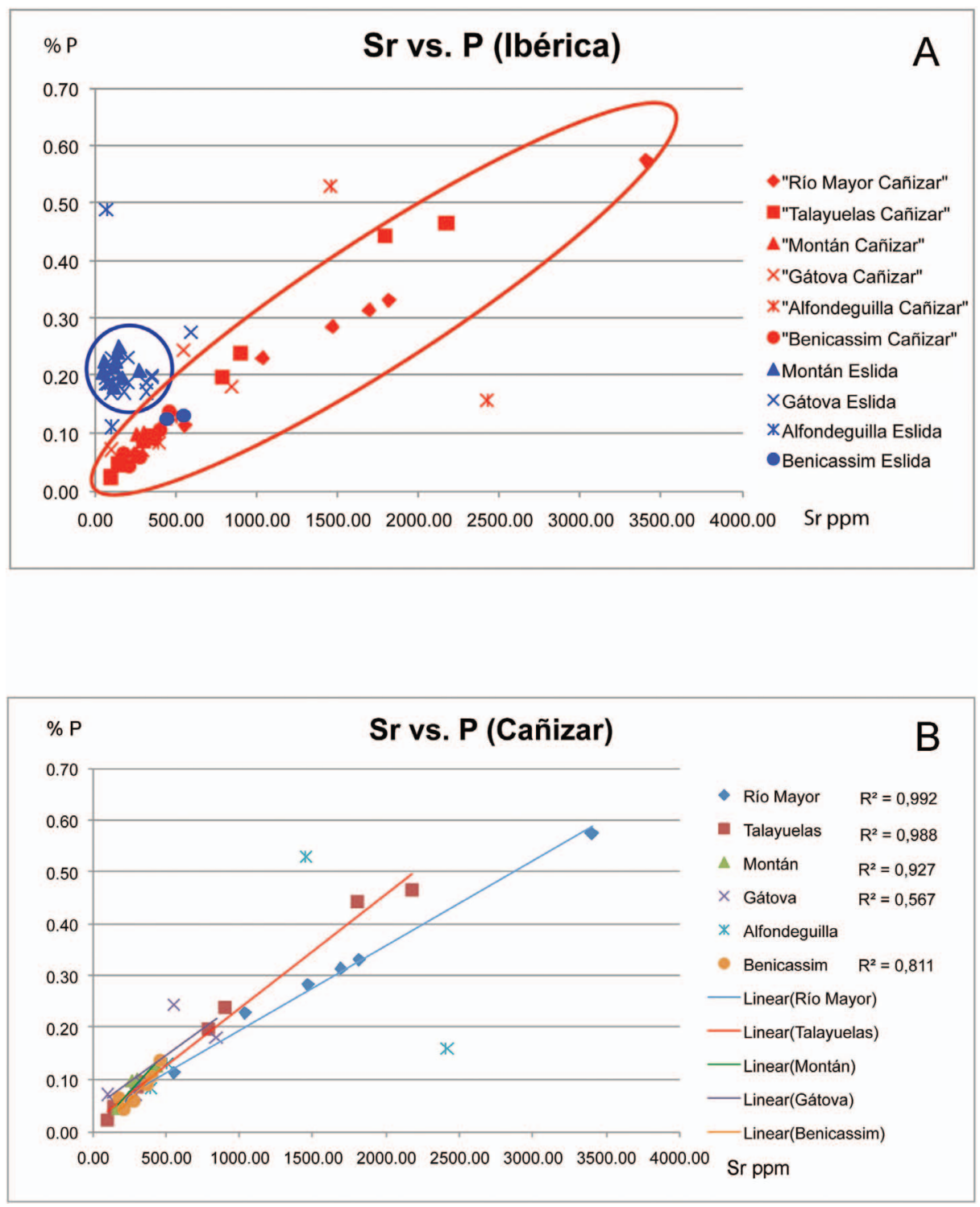

Fig. 10.-A) Plot of P vs. Sr concentration in the studied rocks. Samples from the Cañizar Formation (enclosed by the red line) show a better correlation between P and Sr than those from the Eslida Formation (enclosed by the green circle). Samples from the Eslida Formation display higher P contents relative to Sr, due to the occurrence of abundant detrital phosphates. B) Correlation of P vs. Sr concentrations of the Cañizar Formation in different studied sections. The Alfondeguilla trend line is not included because of the low number of data, which is not considered representative $(n \leq 3)$.

The precipitation of APS minerals requires low-pH conditions (Dill 2001), and kaolinite (closely intergrown with the APS minerals; Fig. 8B) is also typically related to acidic meteoric waters (Hurst and Irwin 1982; Bjørlykke 1998). Thus, it can be concluded that these phases indicate the influence of early diagenetic, acidic meteoric waters.

The APS patches that replace lithic fragments are frequently intergrown with Fe-oxides of pseudocubic morphology (Fig. 8A). Although there is no petrographic evidence of sulfides in these rocks, these iron oxides are probably derived from pseudomorphic replacement of pyrite within the lithic fragments (Reaction 1) that would enhance acidity of the meteoric waters, at least locally, before the APS precipitation.

$$
\left.\mathrm{FeS}_{2}+3.75 \mathrm{O}_{2}+2.5 \mathrm{H}_{2} \mathrm{O}=\mathrm{FeO}(\mathrm{OH})+2 \mathrm{SO}_{4}{ }^{2-}+4 \mathrm{H}^{+} \quad \text { (Reaction } 1\right)
$$

The occurrence of Fe-oxyhydroxides with pseudocubic morphology (after pyrite; Fig. 5D), may provide evidence for an initial phase of acidic pore-waters resulting from pyrite oxidation. Furthermore, the sulfatesulfur isotopic compositions of the APS indicate derivation from sulfide oxidation (see section below). Fe-oxyhydroxide cements in continental sandstones would be also favored under such acid conditions (Dinwiddie et al. 2011). The precipitation of APS and Fe-oxyhydroxides would be favored in this acid environment, e.g., Pe-Piper and Dolansky (2005) suggested that acidity promoted APS formation in sandstones.

Thus, the occurrence of APS minerals could be used as an indicator of acidic conditions. However, quantification of the abundance of APS minerals by petrographic techniques is not possible due to their small size and optical properties (translucence and low birefringence), which makes their identification very difficult. Nonetheless, a semiquantitative estimate could be made using the bulk $\mathrm{Sr}$ content of each sample as an indicator of the abundance of APS minerals. The average APS mineral has $43.8 \mathrm{~g} / \mathrm{mol}$ of $\mathrm{Sr}$. Assuming that all $\mathrm{Sr}$ is in APS minerals, the maximum $\mathrm{Sr}$ value of $3404 \mathrm{ppm}$ would give $2.7 \%$ of APS in samples. Typical Sr concentrations 

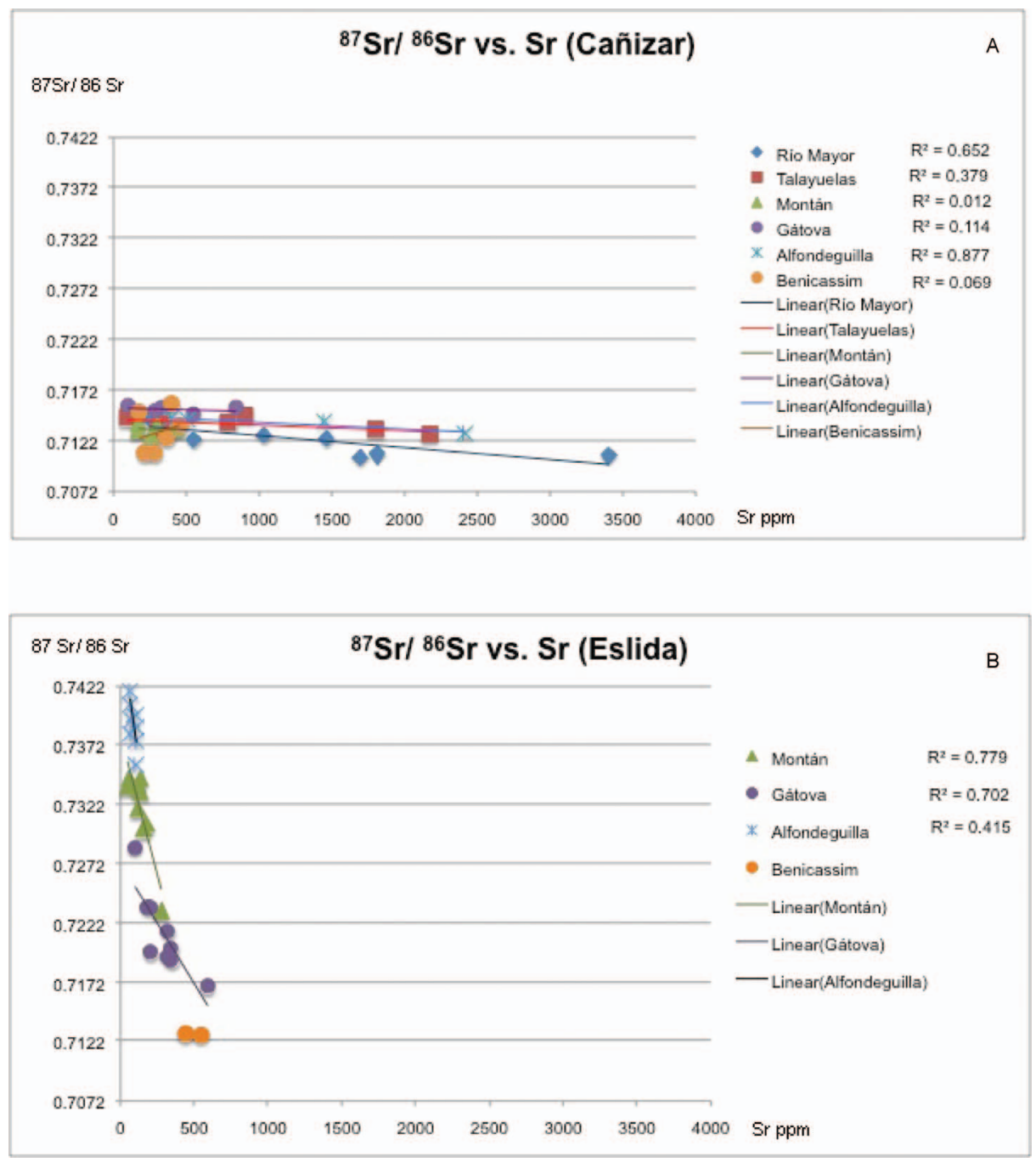

FIG. 11.-Plots of ${ }^{87} \mathrm{Sr} /{ }^{86} \mathrm{Sr}$ vs. Sr concentration of $\left.\mathbf{A}\right)$ Cañizar and $\mathbf{B}$ ) Eslida formations in the studied sections. The trend line for the Eslida Formation in the Benicassim section is not included because of the low number of data $(\mathrm{n} \leq 3)$.

(500 ppm) would give $0.4 \%$ APS minerals. However, not all $\mathrm{Sr}$ is in APS minerals; it also occurs in micas and feldspars as the product of $\mathrm{Rb}$ disintegration, so actual APS mineral concentrations will be lower. The $\mathrm{Sr}$ concentration varies between the two units. In the Cañizar Formation, the $\mathrm{Sr}$ content decreases from the lower and middle part to the top. The $\mathrm{Sr}$ concentration in the Eslida Formation (Fig. 9) is also variable, but in most cases it is lower than in the Cañizar Formation. Furthermore, in the analyzed minerals, Sr and P occur together only in the APS (Table 1B), and there is no appreciable $\mathrm{Sr}$ concentration in other phosphates (Table 1A). Strontium shows a strong positive correlation with phosphorus in samples from the Cañizar Formation (Fig. 10A, B), so both elements would be concentrated in the same mineral phase, that is, in the APS. In contrast, in the Eslida Formation there is a higher concentration of $\mathrm{P}$ relative to $\mathrm{Sr}$ and a weaker correlation (Fig. 10A). Consequently, in the Eslida Formation significant amounts of $\mathrm{P}$ would be hosted by other non-Sr-bearing phosphates (detrital phosphates like monazite or apatite). Thus, the general geochemical trend indicates higher $\mathrm{Sr}$ concentrations, hosted mainly in the APS minerals, in the lower part of Cañizar formation and a decrease from the lower-middle part of the Cañizar Formation to the Eslida Formation. This can be related to a gradual decrease in the acidity of the pore waters.
In addition, the presence of carbonate paleosols in the Eslida Formation, which require conditions of higher $\mathrm{pH}$, is coincident with the general decrease of $\mathrm{Sr}$ concentration and therefore with lower contents of APS minerals in the rocks. This could be indicative of a lower acidity of waters and a diminution of possible volcanic inputs. Furthermore, the presence of carbonates during early diagenesis would have buffered the influence of acidic meteoric waters due to pyrite oxidation, preventing the dissolution of detrital phosphates and thus precluding APS formation.

\section{Possible Sources of Sr and $S$}

As previously mentioned, early diagenetic APS minerals are the only significant host for both $\mathrm{Sr}$ and $\mathrm{S}$. However, although $\mathrm{Sr}$ is present mainly in APS minerals (Table 1B), it could, as previously discussed above, also be present in small amounts (below detection limits for EMPA analysis) in other detrital minerals. Thus, detrital minerals, depending on their source areas, could influence the ${ }^{87} \mathrm{Sr} /{ }^{86} \mathrm{Sr}$ ratios. The range of ${ }^{87} \mathrm{Sr} /{ }^{86} \mathrm{Sr}$ ratios of the rocks of the Eslida Formation (0.7127-0.7422) is far wider and more radiogenic than the range in Cañizar Formation (0.71050.7158). The higher values are common from granitic and metamorphic 
TABLE 2.- ${ }^{87} \mathrm{Sr} /{ }^{86} \mathrm{Sr}$ values measured in whole rock analysis.

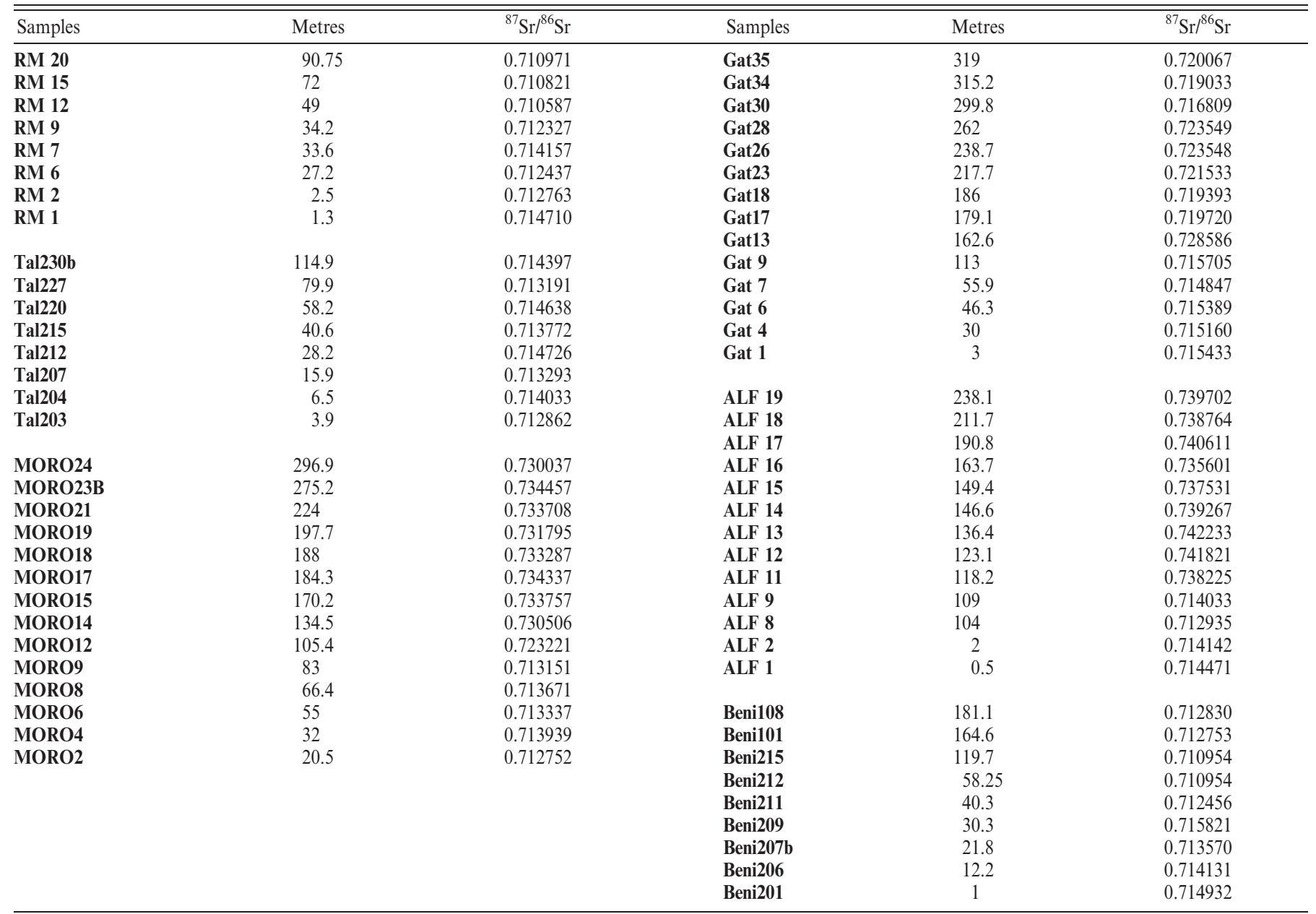

TABLE 3.- $\delta^{34} S$ values measured in the different sections.

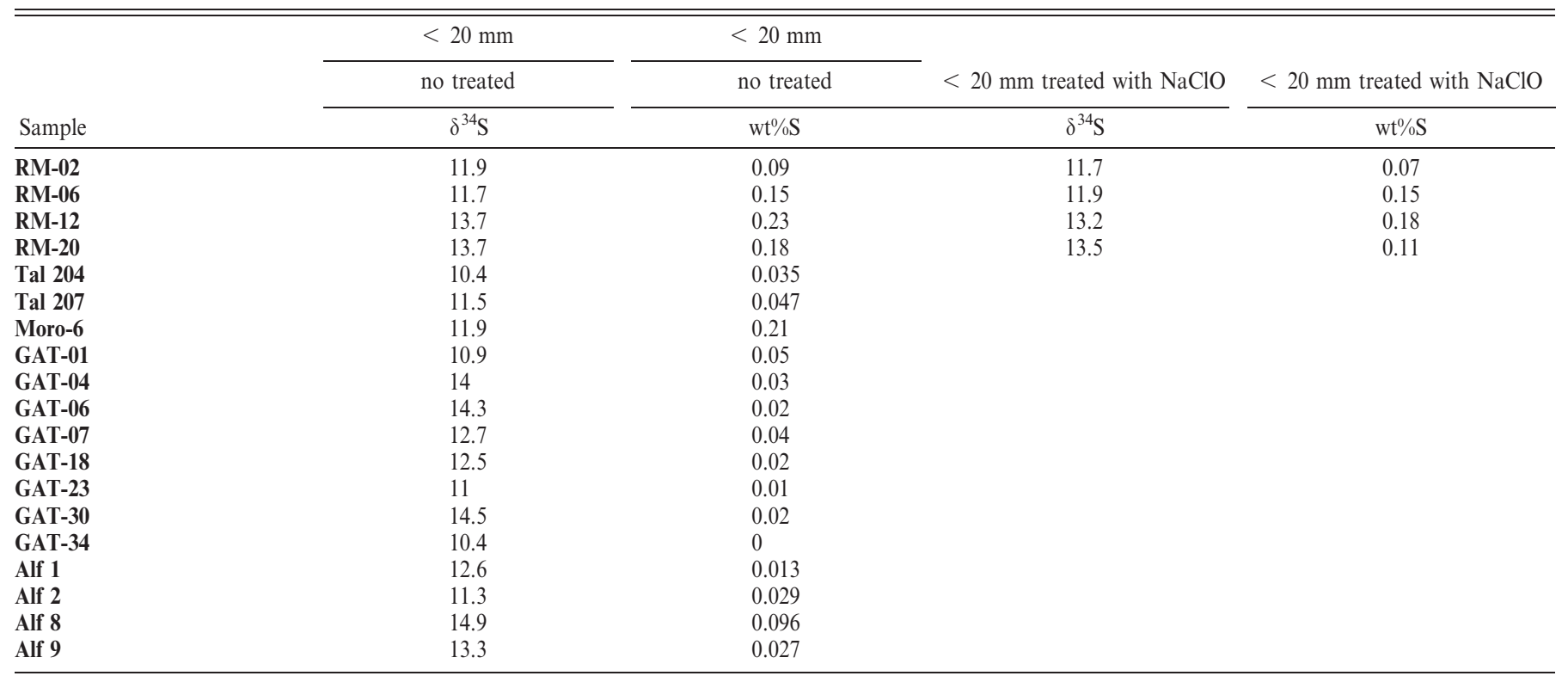




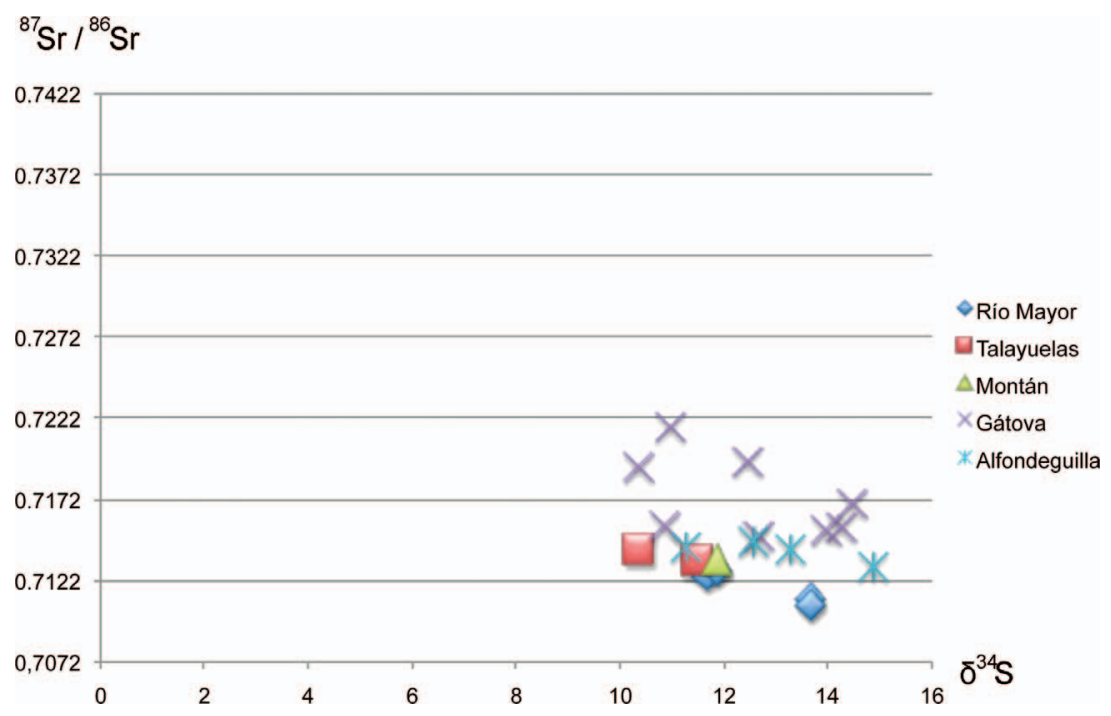

FIG. 12.-Plot of ${ }^{87} \mathrm{Sr} /{ }^{86} \mathrm{Sr}$ vs. $\delta^{34} \mathrm{~S}$ values of the various studied sections from Cañizar and Eslida formations. rocks, which are more radiogenic than sedimentary and volcanic rocks, seawater, or volcanic aerosols (Allègre 2008). Therefore the dissolution of pre-existing detrital minerals like feldspars or micas could have provided an ${ }^{87} \mathrm{Sr}$-rich source incorporated in the APS resulting in high ${ }^{87} \mathrm{Sr} /{ }^{86} \mathrm{Sr}$ ratios. Because the ${ }^{87} \mathrm{Sr} /{ }^{86} \mathrm{Sr}$ values of the Eslida Formation are significantly more radiogenic than in the Cañizar Formation, they point to a change in the provenance. This was also found by Gómez-Grass (1993) and by Arribas et al. $(1985,2007)$ in continental Triassic sediments of Coastal Catalonian Ranges and the northwest of the Iberian Ranges, respectively.

If dissolution of detrital minerals were the only source of $\mathrm{Sr}$, then there should be a positive relationship between $\mathrm{Sr}$ concentration and ${ }^{87} \mathrm{Sr} /{ }^{86} \mathrm{Sr}$ ratios. However, the plot of the ${ }^{87} \mathrm{Sr} /{ }^{86} \mathrm{Sr}$ ratios vs. $\mathrm{Sr}$ concentration (Fig. 11) shows that there is a negative correlation between them in the Cañizar and Eslida formations. Samples displaying higher Sr content, and thus higher APS contents, show lower ${ }^{87} \mathrm{Sr} /{ }^{86} \mathrm{Sr}$ values (Fig. 11). These data suggest the influence of a source of nonradiogenic $\mathrm{Sr}$ other than that derived from detrital minerals. The influence of this source is better recognized in horizons with high $\mathrm{Sr}$ concentration that show lower ${ }^{87} \mathrm{Sr} /{ }^{86} \mathrm{Sr}$ ratios, whereas the horizons with lower $\mathrm{Sr}$ concentrations have high ${ }^{87} \mathrm{Sr} /{ }^{86} \mathrm{Sr}$ ratios, mostly reflecting a signature inherited from the detrital minerals.

The slopes of the correlation lines between $\mathrm{Sr}$ concentration and ${ }^{87} \mathrm{Sr} /{ }^{86} \mathrm{Sr}$ ratios (Fig. 11) are significantly higher in the sections from the Eslida Formation. This indicates that the influence of the nonradiogenic source is higher in the Eslida Formation than in the Cañizar Formation, resulting in larger variations despite the lower $\mathrm{Sr}$ concentration. Therefore, the ${ }^{87} \mathrm{Sr} /{ }^{86} \mathrm{Sr}$ ratio of the less-radiogenic source should be lower than the minimum ${ }^{87} \mathrm{Sr} /{ }^{86} \mathrm{Sr}$ ratio measured in the Cañizar Formation, which is 0.7105 .

There are two different sources of $\mathrm{Sr}$ with low ${ }^{87} \mathrm{Sr} /{ }^{86} \mathrm{Sr}$ ratios that could satisfy this condition: marine and/or volcanic sources. The ${ }^{87} \mathrm{Sr} /{ }^{86} \mathrm{Sr}$ of marine Lower-Middle Triassic carbonates are around 0.7080 (Prokoph et al. 2008), and so a contemporary marine input would provide a source of nonradiogenic Sr. However, the rocks of the Cañizar and Eslida formations were deposited in continental environments, and there is no sedimentological evidence for a marine environment, so a direct marine input can be discarded. Nevertheless, an indirect marine influence could be possible by aerosols, which can be significant in arid environments. This mechanism has been described in present-day Australian lakes (Bird et al. 1989; Alpers et al. 1992; Bowen and Benison 2009). The environment of these modern lakes is consistent with the arid and warm conditions described for the Early Triassic, and many of them have acidic water compositions from which alunite-jarosite minerals are currently being precipitated (Alpers et al. 1992). Despite the remote location of these lakes from the sea coast $(160-300 \mathrm{~km})$, marine aerosols have been proposed as one of the sources for $\mathrm{S}$ and $\mathrm{Sr}$ in both lake waters and solid sulfate phases (alunite, jarosite, or gypsum; McArthur et al. 1989; Chivas et al. 1991; Alpers et al. 1992). Like the APS minerals studied in this work, alunite-jarosite precipitates as small crystal aggregates of 1-5 $\mu \mathrm{m}$ size (Alpers et al. 1992), corresponding to alteration products of other minerals during the early stages of diagenesis. It should be emphasized that although APS minerals belong to the alunite-jarosite supergroup, there are some compositional differences between them, the APS being solid solutions among sulfate-phosphate end members and showing higher chemical complexity. These differences would be related to the availability of distinct elements depending on the source rocks.

Sulfur is present only in the APS minerals, because no other sulfate or sulfide minerals are observed in these samples. Furthermore, the similarity in S-isotope results of samples treated and untreated with $\mathrm{NaClO}$ (Table 3) show that there is no significant concentration of sulfides. Thus, the measured bulk S-isotope compositions reflect the composition of APS. The dominant natural sources of sulfate in terrestrial waters are marine aerosol inputs, $\mathrm{SO}_{4}{ }^{2-}$ in rainwater, and weathering of bedrock sulfates and sulfides (Robinson and Bottrell 1997). A marine aerosol has already been suggested as the likely source for the $\mathrm{Sr}$ input, simultaneously supplying pore-water sulfate ions for APS formation. Such sulfate would have been isotopically heavy, because an Early Triassic marine aerosol source would have Early Triassic marine values, that is, $\approx+28.3 \%$ (Claypool 1980) to $+21.5 \%$ (Kampschulte and Strauss 2004). Thus, the analyzed APS mineral compositions $\left(\delta^{34} \mathrm{~S}=+11\right.$ to $+14 \%$ ) may reflect a mixture of marine aerosol sulfate with another isotopically lighter sulfur source, certainly with $\delta^{34} \mathrm{~S}<10 \%$, and probably even lighter than this value. Such a source could be provided by the oxidation of pre-existing sulfides, because diagenetic sulfide is generally depleted in ${ }^{34} \mathrm{~S}$ (Bottrell and Newton 2006). As described in previous section, APS are in some cases associated with Fe-oxihydroxides with pseudocubic morphologies that could be inherited from pyrite oxidation (Fig. 8A). The weathering of pyrite from the lithic metamorphic fragments would result in an input of acid waters enriched in light sulfur. The Sisotope compositions of APS minerals are thus consistent with a component of sulfate from pyrite oxidation that would lead to $\delta^{34} \mathrm{~S}$ 
compositions lighter than Triassic marine-derived values. A similar mechanism was proposed by Birnbaum and Coleman (1978), who cited the dissolution of pyrite within basement rocks to explain the light isotopic input of sulfur in the Tertiary Ebro Basin.

Although there is no direct evidence of volcanic activity in the study area, it has been widely suggested as a cause of environmental damage during the Early Triassic (Benton 2003; Erwin 2006; Galfetti et al. 2007; Payne and Kump 2007; Xie et al. 2010). The input of volcanic aerosols would decrease the Sr ratio and could also account for some of the ${ }^{34} \mathrm{~S}$ depleted sulfur needed to balance marine sulfate inputs and also provide part of the acidity required. However, if volcanic aerosol inputs were the dominant source of $\mathrm{S}$ and $\mathrm{Sr}$, then some correlation between $\delta^{34} \mathrm{~S}$ and ${ }^{87} \mathrm{Sr} /{ }^{86} \mathrm{Sr}$ might be expected, inasmuch as this source would be associated with low values of both. However, such correlation does not exist (Fig. 12), probably because the sediment source control and marine aerosol input discussed above exerts a stronger influence on $\mathrm{Sr}$ isotope composition than volcanic aerosol inputs.

\section{Paleonvironmental Implications}

During the deposition of the Cañizar Formation (Olenekian?-Aegian) braided fluvial systems interbedded with eolian sediments formed under warm and arid climate conditions with a very high evaporation rate (López-Gómez et al. 2012). This, combined with an important wind influence (Fluteau et al. 2003), would have provided inputs of marine aerosols. Furthermore, meteoric-water acidity could be locally increased by pyrite oxidation or by the input of volcanic aerosols. The lack of any fossil content in the lower part of the Cañizar Formation could be a consequence of these unfavorable environmental conditions, as has been recognized worldwide in other units, causing a delay of the biotic recovery during the Early Triassic after the Permian-Triassic life crisis (Solé et al. 2002; Woods 2005; Chen et al. 2007; Bottjer et al. 2008; Preto et al. 2010; Hermann et al. 2011).

These unfavorable conditions changed during the Aegian (Fig. 3), from MBS-5 to the top of the Cañizar Formation (Galán-Abellán 2011) and the Eslida Formation. From the MBS-5 onwards, the first appearance of tetrapod footprints, organic matter, and other biotic structures are found in the study area (Gand et al. 2010; López-Gómez et al. 2012), suggesting a change in the climatic conditions to less arid and more temperate. The eolian influence disappeared, as did the impact of marine aerosols, due to a lower evaporation rate, reflected in increased ${ }^{87} \mathrm{Sr} /{ }^{86} \mathrm{Sr}$ ratios. This can be correlated with the decrease in Sr content and, therefore, with APS abundance (Fig. 9), which in turn indicates a reduction in acidity and probably also volcanic input. Conditions were also less acidic during the deposition of the Eslida Formation (Aegian-Pelsonian), as indicated by a variable but general decrease in APS concentration and an increase in carbonate paleosols, but also more humid as reflected the change in fluvial style to braided systems with wide flood plains (Arche and LópezGómez 2005). This environment would be more favorable to biotic colonization, as revealed by the more abundant and diverse fossil content (tetrapod traces, plants, and invertebrates; Fig. 3; Bèthoux et al. 2009; Gand et al. 2010; Galán-Abellán 2011).

Therefore, the MBS-5 clearly marks significant changes in the paleoenvironmental conditions that mark the beginning of the recovery in the eastern part of the Iberian Peninsula (Galán-Abellán 2011). This discontinuity could be correlated (based on sedimentological criteria) with the Hardegsen unconformity of the northwest European basins (López-Gómez et al. 2012) that also marks these changes in other areas. Our mineralogical and geochemical data (i.e., presence of APS minerals, $\mathrm{Sr}$ and $\mathrm{S}$ isotopes) potentially provides new and valuable tools to compare paleoenvironmental changes and their influence on the Triassic biotic recovery of different basins.

\section{CONCLUSIONS}

The geochemical and mineralogical study of continental Triassic sandstones from the Iberian Ranges shows a relationship between the influence of environmental changes in the formation of APS minerals and their $\mathrm{Sr}$ and $\mathrm{S}$ sources. APS formation is related to acidic meteoric waters during early diagenesis, and they are the only host for $\mathrm{S}$ and the main host for $\mathrm{Sr}$ in the studied rocks. Acidity mainly resulted from pyrite oxidation and was possibly increased by volcanic aerosols. Both sulfide oxidation and volcanic aerosol would have provided ${ }^{34} \mathrm{~S}$-depleted sulfate. On the other hand, marine aerosols provided ${ }^{34} \mathrm{~S}$-enriched sulfate. In addition, both marine and volcanic aerosols could have supplied nonradiogenic Sr. Dissolution of detrital K-feldspar/micas would have contributed to increase radiogenic $\mathrm{Sr}$.

The higher APS mineral concentration of the Cañizar formation compared with the overlying Eslida Formation indicates that pore-water $\mathrm{pH}$ increased with time, inhibiting APS formation. This resulted from a smaller influence of pyrite oxidation and variations in the volcanic or marine aerosol input. These variations probably resulted from changes in paleoenvironmental conditions, from a dry and arid climate during the Olenekian-early Anisian (Cañizar Fm.), towards more seasonal and humid climate during the middle Anisian (Eslida Fm.). These variations would lead to favorable conditions for the beginning of the biotic recovery after the Permian-Triassic life crisis in this part of the Iberian Peninsula, and also agree with the changes reported for other European basins of the West Tethys realm.

\section{ACKNOWLEDGMENTS}

The authors thank Gilberto Herrero and Beatriz Moral for thin-section preparation, Belén Soutullo for XRD analyses, and Dra. C. Galindo and the staff of CAI of Geochronology and Isotope Geochemistry (UCM) and Centro Nacional de Microscopía Electronica of the Complutense University (Madrid, Spain) for their technical support. This work is a contribution from Projects CGL 2008-00093, CGL2010-09503-E, and CGL 2011-24408 of the Spanish Research Ministry and from Projects UCM-BSCH-GR58/08: Análisis de Cuencas (910429) and Paleoclimas (910198) Universidad Complutense-Comunidad Autónoma de Madrid (Spain). Galán-Abellán is grateful to the Spanish Research Ministry for the FPI and travel grants (BES2006-12548) and the DAAD scholarship in the Steinmann Institut-Geologie (Universität-Bonn).

\section{REFERENCES}

Allėgre, C.J., 2008, Isotope Geology: New York, Cambridge University Press, 512 p Alpers, C.N., Rye, R.O., Nordstrom, D.K., White, L.D., and King, B., 1992 Chemical, crystallographic and stable isotopic properties of alunite and jarosite from acid-hypersaline Australian lakes: Chemical Geology, v. 96, p. 203-226.

Arche, A., AND López-Gómez, J., 1996, Origin of the Permian-Triassic Iberian Basin, central-eastern Spain: Tectonophysics, v. 266, p. 443-464.

Arche, A., And López-Gómez, J., 1999a, Tectonic and geomorphic controls on the fluvial styles of the Eslida Formation, Middle Triassic, eastern Spain: Tectonophysics, v. 315 , p. $187-207$.

Arche, A., AND López-Gómez, J., 1999b, Subsidence rates and fluvial architecture of rift-related Permian and Triassic alluvial sediments of the southeast Iberian Range, eastern Spain, in Smith, N.D., and Rogers, J., eds., Fluvial Sedimentology IV: International Association of Sedimentologists, Special Publication 28, p. 283-304.

Arche, A., And López-Gómez, J., 2005, Sudden changes in fluvial style across the Permian-Triassic boundary in the eastern Iberian Ranges, Spain: analysis of possible causes: Palaeogeography, Palaeoclimatology, Palaeoecology, v. 229, p. 104-126.

Arribas, J., 1985, Base litoestratigráfica de las facies Buntsandstein y Muschelkalk de la Rama Aragonesa de la Cordillera Ibérica (Zona Norte): Estudios Geológicos, v. 41, p. $47-57$.

Arribas, A., Mas, R., Arribas, M.E., Ochoa, M., GonzÁlez, L., 2007, Sandstone petrofacies in the Northwestern sector of the Iberian Basin: Journal of Iberian Geology, v. 331, p. 91-206.

Benito, M.I., De la Horra, R., Barrenechea, J.F., López-Gómez, J., Rodas, M., Alonso-Azcárate, J., Arche, A., And Luque, J., 2005, Late Permian continental sediments in the SE Iberian Ranges eastern Spain: petrological and mineralogical characteristics and palaeoenvironmental significance: Palaeogeography, Palaeoclimatology, Palaeoecology, v. 229, p. 24-39. 
Benito, M.I., De la Horra, R., López-Gómez, J., Barrenechea, J.F., Luque, J., and Arche, A., 2011, Shallow burial dolomitization of Middle-Upper Permian paleosols in an extensional tectonic context (SE Iberian Basin, Spain): controls on temperature of precipitation and source of fluids: Sedimentary Geology, v. 237, p. 135-149.

Benton, M.J., 2003, When Life Nearly Died: The Greatest Mass Extinction of All Time: London, Thames \& Hudson, $336 \mathrm{p}$.

Béthoux, O., De la Horra, R., Benito, M.I., Barrenechea, J.F., Galán, A.B., and López-Gómez, J., 2009, A new triadotypomorphan insect from the Anisian (Middle Triassic), Buntsandstein facies, Spain: Journal of Iberian Geology, v. 35, p. 179-184

Bird, M.I., Andrew, A.S., Chivas, A.R., And Lock, D.E., 1989, An isotopic study of surficial alunite in Australia, 1: hydrogen and sulphur isotopes: Geochimica et Cosmochimica Acta, v. 53, p. 3223-3237.

Birnbaum, S.J., And Coleman, M., 1979, Source of sulphur in the Ebro Basin (northern Spain) Tertiary nonmarine evaporate deposits as evidenced by sulphur isotopes: Chemical Geology, v. 25, p. 163-168.

BJøRlykKe, K., 1998, Clay mineral diagenesis in sedimentary basins: a key to the prediction of rock properties: examples from the North Sea Basin: Clay Minerals, v. 33, p. $15-34$.

Botha, J., AND Smith, R.M.H., 2006, Rapid vertebrate recuperation in the Karoo Basin of South Africa following the end-Permian extinction: Journal of African Earth Sciences, v. 45, p. 502-514.

Bottuer, D.J., Clapham, M.E., Fraiser, M.L., and Powers, C.M., 2008, Understanding the mechanisms for the end-Permian mass extinction and the protracted Early Triassic aftermath and recovery: GSA Today, v. 18, p. 4-10.

Bottrell, S.H., AND Newton, R.J., 2006, Reconstruction of changes in global sulphur cycling from marine sulphate isotopes: Earth-Science Reviews, v. 75, p. 59-83.

Boulouard, C., AND Viallard, P., 1982, Réduction ou lacune du trias inférieur sur la bordure meditérraneenne de la Chaîne Ibérique: arguments palynologiques: Comptes rendus de l'Académie des sciences, Série 2, Sciences de la Terre et des Planètes, v. 295, p. $803-808$

Bourquin, S., Péron, S., And Durand, M., 2006, Lower Triassic sequence stratigraphy of the western part of the Germanic Basin (west of Black Forest): fluvial system evolution through time and space: Sedimentary Geology, v. 186, p. 187-211.

Bourquin, S., Durand, M., Dies, J.B., Broutin, J., and Fluteau, F., 2007, The Permian-Triassic boundary and Lower Triassic sedimentation in the Western European Basins: an overview: Journal of Iberian Geology, v. 33, p. 221-236.

Bourquin, S., Bercovici, A., López-Gómez, J., Diez, J.B., Broutin, J., Ronchi, A., Durand, M., Arche, A., Linol, B., and Amour, F., 2011, The Permian-Triassic transition and the onset of Mesozoic sedimentation at the northeastern peri-Tethyan domain scale: paleogeographic maps and geodynamic implications: Palaeogeography, Palaeoclimatology, Palaeoecology, v. 299, p. 265-280.

Bowen, B.B., AND Benison, K.C., 2009, Geochemical characteristics of naturally acid alkaline saline lakes in southern Western Australia: Applied Geochemistry, v. 24, p. $268-284$.

Cassinis, G., Toutin-Morin, N., And Virgili, C., 1992, Permian and Triassic events in the continental domains of Mediterranean Europe, in Zunyi, Y., Sweet, W.C., Dickins, J.M., and Yin, H., eds., Permo-Triassic Events in the Eastern Tethys; Stratigraphy, Classification and Relations with the Western Tethys World and Regional Geology: Cambridge, U.K., Cambridge University Press, p. 60-77.

Chen, Z.Q., Tong, J., Kaiho, K., and Kawahata, H., 2007, Onset of biotic and environmental recovery from the end-Permian mass extinction within 1-2 million years: a case study of the lower Triassic of the Meishan section, South China: Palaeogeography, Palaeoclimatology, Palaeoecology, v. 252, p. 176-187.

Chivas, A.R., Andrew, A.S., Lyons, W.B., Bird, M.J., and Donnelly, T.H., 1991, Isotopic constraints on the origin of salts in Australian playas. 1. Sulphur: Palaeogeography, Palaeoclimatology, Palaeoecology, v. 84, p. 309-332.

Claypool, G.E., Holser, W.T., Kaplan, I.R., Sakai, H., and ZaK, I., 1980, The age curves of sulphur and oxygen isotopes in marine sulphate and their mutual interpretation: Chemical Geology, v. 28, p. 199-260.

Coney, L., Reimold, W.U., Hancox, P.J., Mader, D., Koeberl, C., McDonald, I., Struck, U., Vajda, V., and Kamo, S.L., 2007, Geochemical and mineralogical investigation of the Permian-Triassic boundary in the continental realm of the southern Karoo Basin, South Africa: Paleoworld, v. 16, p. 67-104.

Corsetti, F.A., Baud, A., Marenco, P.J., and Richoz, S., 2005, Summary of Early Triassic carbon isotope records: Comptes Rendus Palévol, v. 4, p. 405-418.

De la Cruz B., Marfil, R., De la Peña, J.A., and Arribas, J., 1987, Procedencia y evolución diagenética de las areniscas permo-triásicas de la Cordillera Ibérica (Sierra de Albarracín-Boniches-Talayuelas, provincias de Teruel y cuenca): Cuadernos de Geología Ibérica, v. 11, p. 493-514.

De Vicente, G., Vegas, R., Muñoz-Martín, A., Van Wees, J.D., Casa-Sainz, A., Sopeña, A., Sánchez-Moya, A., Arche, A., López-Gómez, J., Olaiz, A., And FERNÁNDEZ-LozANO, J., 2009, Oblique strain partitioning and transpression on an inverted rift: the Castillian Branch of the Iberian Chain: Tectonophysics, v. 470, p. 224-242.

Diedrich, C.G., 2009, Pelaeogeographic evolution of the marine Middle Triassic marine Germanic Basin changements, with emphasis on the carbonate tidal flat and shallow marine habitats of reptiles in Central Pangea: Global and Planetary Change, v. 65, p. $27-55$.

Díez, J.B., Grauvogel-Stamm, L., Broutin, J., Ferrer, J., Gisbert, J., and Linan, E., 1996, Première découverte d'une paléoflore anisiennedans le faciès "Buntsandstein" de la branche aragonaise de la Cordillère Ibérique (Espagne): Comptes rendus de l'Académie des sciences, Série 2, Sciences de la Terre et des Planètes, v. 323, p. 341347.
DiLL, H.G., 2001, The geology of aluminum phosphates and sulphates of the alunite group minerals: a review: Earth-Sciences Reviews, v. 53, p. 35-93.

Dinaress-Turrell, J., Díez, J B., Rey, D., and Arnal, I., 2005, "Buntsandstein", magnetostratigraphy and biostratigraphic reappraisal from eastern Iberia: Early and Middle Triassic stage boundary definitions through correlation to Tethyan sections: Palaeogeography, Palaeoclimatology, Palaeoecology, v. 229, p. 158-177.

Dinwiddie, C.L., Chan, M.A., McGinnis, R.N., Myers, J.L., and Holliday, W.S 2011, Chronicles of vadose zone diagenesis: cone-shaped iron oxide concretions, Triassic Trujillo Formation, Palo Duro Canyon, Texas: Geofluids, v. 11, p. 87-96.

Dolenec, T., Lojen, S., and Ramovs, A., 2001, The Permian-Triassic boundary in Western Slovenia (Idrijca Valley section): magnetostratigraphy, stable isotopes, and elemental variations: Chemical Geology, v. 175, p. 175-190.

Doubinger, J., López-Gómez, J., And Arche, A., 1990, Pollen and spores from the Permian and Triassic sediments of the Southeastern Iberian ranges, Cueva de Hierro (Cuenca) to Chelva-Manzanera (Valencia-Teruel) region, Spain: Review of Palaeobotany and Palynology, v. 66, p. 25-45.

ERwin, D.H., 2006, Extinction: How Life on Earth Nearly Ended 250 Million Years Ago: Princenton, Princenton University Press, 296 p.

Fluteau, F., Basse, J., Broutin, J., and Ramstein, G., 2003, The Late Permian climate. What can be inferred from climate modelling concerning Pangea Scenarios and Hercynian range altitude?: Palaeogeography, Palaeoclimatology, Palaeoecology, v. 167 , p. $39-71$

FolK, R.L., 1974, Petrology of Sedimentary Rocks, Austin, Texas, Hemphills, 182 p.

Fraiser, M.L., And BotTJer, D.J., 2007, Elevated atmospheric $\mathrm{CO}_{2}$ and the delayed biotic recovery from the end-Permian mass extinction: Palaeogeography, Palaeoclimatology, Palaeoecology, v. 252, p. 164-175.

Galán-Abellán, A.B., 2011, Sedimentological, mineralogical, geochemical and biotic variations in the SE Iberian and Catalonian Coastal Ranges during the Early and Middle Triassic period (Buntsandstein facies): recovery implications after the Permian-Triassic life crisis [Ph.D. thesis]: Universidad Complutense de Madrid, 295 p., ISBN: 978-84-695-1198-5.

Galán-Abellán, A.B., Fernández-Barrenechea, J., López-Gómez, J., Lago-San José, M., And Benito-Moreno, M.I., 2008, Early Triassic-Anisian Continental Sediments from SE Iberian Ranges: sedimentological and mineralogical features: Macla, v. 9 p. $105-106$

Galfetti, T., Hochuli, P.A., Brayard, A., Bucher, H., Weissert, H., and Os Vigran, J., 2007, Smithian-Spathian boundary event: evidence for global climatic change in the wake of the end-Permian biotic crisis: Geology, v. 35, p. 291-294.

Gand, G., De la Horra, R., Galán-Abellán, B., López-Gómez, J., FernándezBerrenechea, J., Arche, A., And Benito, M.I., 2010, New ichnites from the Middle Triassic of the Iberian Ranges (Spain): palaeoenvironmental and palaeogeographical implications: Historical Biology, v. 22, p. 40-56.

Guidry, M.W., And MackenZIE, F.T., 2003, Experimental study of igneous and sedimentary apatite dissolution: control of $\mathrm{pH}$, distance from equilibrium, and temperature on dissolution rates: Geochimica et Cosmochimica Acta, v. 67, p. 29492963

Grauvogel-Stamm, L., And Ash, S.R., 2005, Recovery of the Triassic land flora from the end-Permian life crisis: Comptes Rendus Palévol, v. 4, p. 525-540.

Hallam, A., and Wignall, P.B., 1997, Mass Extinctions and Their Aftermath: New York, Oxford University Press, 319 p.

Hermann, E., Hochuli, P.A., Bucher, H., Brühwiler, T., Hautmann, M., and Ware, D., AND RooHI, G., 2011, Terrestrial ecosystems on North Gondwana following the end-Permian mass extinction: Gondwana Research, v. 20, p. 630-637.

Hurst, A., AND IRwIN, H., 1982, Geological modeling of clay diagenesis in sandstones: Clay and Clay Minerals, v. 17, p. 5-22.

Kampschulte, A., and Strauss, H., 2004, The sulphur isotopic evolution of Phanerozoic seawater based on the analysis of structurally substituted sulphate in carbonates: Chemical Geology, v. 204, p. 255-286.

Korte, C., Kozur, H.W., Bruckschein, P., And Veizer, J., 2003, Strontium Isotope evolution of Late Permian and Triassic seawater: Geochimica et Cosmochimica Acta, v. 67, p. $47-62$.

Kozur, H.W., 1998, Some aspects of the Permian-Triassic boundary (PTB) and the possible causes of the biotic crisis around this boundary: Palaeogeography, Palaeoclimatology, Palaeoecology, v. 143, p. 227-272.

Lago, M., De la Horra, R., Ubide, T., Galé, C., Galán-Abellán, A.B., Barrenechea, J.F., López-Gómez, J., Benito, M.I., Arche, A., Alonso-Azcárate, J., And Luque, F.J., 2012, First report of a Middle-Upper Permian magmatism in the SE Iberian Ranges: characterisation and comparison with coeval magmatisms in the western Tethys: Journal of Iberian Geology, v. 38 p. 331-338

López-Gómez, J., AND ARche, A., 1993a, Sequence stratigraphic analysis and paleogeographic interpretation of the Buntsandstein and Muschelkalk facies (Permo-Triassic) in the SE Iberian Range, E Spain: Palaeogeography, Palaeoclimatology, Palaeoecology, v. 103, p. 179-201.

López-Gómez, J., AND ARCHE, A., 1993b, Architecture of the Cañizar fluvial sheet sandstones, Early Triassic, Iberian Ranges, eastern Spain, in Marzo, M., and Puigdefábregas, C., eds., Alluvial Sedimentation: International Association of Sedimentologists, Special Publication 17, p. 363-381.

López-Gómez, J., Arche, A., Calvet, F., And Goy, A., 1998, Epicontinental marine carbonate sediments of the Middle and Upper Triassic in the westernmost part of the Tethys Sea, Iberian Peninsula: Zentralblatt für Geologie und Paläontologie, Teil 1, v. 9-10, p. 1033-1084. 
López-Gómez, J., Arche, A., and Pérez-López, A., 2002, Permian and Triassic, in Gibbons, W., and Moreno, T., eds., The Geology of Spain: The Geological Society of London, p. 185-221.

López-Gómez, J., Arche, A., Marzo, M., And Durand, M., 2005, Stratigraphical and palaeogeographical significance of the continental sedimentary transition across the Permian-Triassic boundary in Spain: Palaeogeography, Palaeoclimatology, Palaeoecology, v. 229, p. 3-23.

López-Gómez, J., Galán-Abellán, B., De la Horra, R., Barrenechea, J.F., Arche, A., Bourquin, S., Marzo, M., And Durand, M., 2012, Sedimentary evolution of the continental Early-Middle Triassic Cañizar Formation (Central Spain): implications for life recovery after the Permian-Triassic crisis: Sedimentary Geology, v. 249-250, p. $26-44$.

Martin-Martín, J.D., Gómez-Gras, D., Sanfeliu, T., Thiry, M., Ruiz-Cruz, M.D., and Franco, F., 2007, Extensive dickitization of the Permo-Triassic fluvial sandstones from the eastern Iberian Range, Spain: Clays and Clay Minerals, v. 55, p. 481-490.

Maruoka, T., Koeberl, C., Hancox, P.J., And Reimold, W.U., 2003, Sulphur geochemistry across a terrestrial Permian-Triassic boundary section in the Karoo Basin, South Africa: Earth and Planetary Science Letters, v. 206, p. 101-117.

McArthur, J.M., Turner, J., Lyons, W.B., And Thirlwall, M.F., 1989, Salt sources and water-rock interaction on the Yilgarn Block, Australia: isotopic and major element tracers: Applied Geochemistry, v. 4, p. 79-92.

McArthur, J.M., Howarth, R.J., And Bailey, T.R., 2001, Strontium isotope stratigraphy: LOWESS Version 3: best fit to the marine Sr-isotope curve for 0 $509 \mathrm{Ma}$ and accompanying look-up table for deriving numerical age: The Journal of Geology, v. 109, p. 155-170.

Newton, R.J., Pevitt, E.L., Wignall, P.B., And Bottrell, S.H., 2004, Large shifts in the isotopic composition of seawater sulphate across the Permo-Triassic boundary in northern Italy: Earth and Planetary Science Letters, v. 218, p. 331-345.

Payne, J.L., AND Kump, L.R., 2007, Evidence for recurrent Early Triassic massive volcanism from quantitative interpretation of carbon isotope fluctuations: Earth and Planetary Science Letters, v. 256, p. 264-277.

Payne, J.L., Lehrmann, D.J., Wei, J., Orchard, M.J., Schrag, D.P., and Knoll, A.H., 2004, Large perturbations of the carbon cycle during recovery from the End-Permian extinction: Science, v. 305, p. 506-509.

Payne, J.L., Summers, M., Rego, B.L., Altiner, D., Wei, J., Yu, M., and Lehrmann, D.J., 2011, Early and Middle Triassic trends in diversity, evenness, and size of foraminifers on a carbonate platform in south China: implications for tempo and mode of biotic recovery from the end-Permian mass extinction: Paleobiology, v. 37, p. 409-425.

Peng, Y., Zhang, S., Yu, T., Yang, F., Gao, Y., and Shi, G.R., 2005, High-resolution terrestrial Permian-Triassic eventostratigraphic boundary in western Guizhou and eastern Yunnan, southwestern China: Palaeogeography, Palaeoclimatology, Palaeoecology, v. 215, p. 285-295.

Pe-Piper, G., and Dolansky, L.M., 2005, Early diagenetic origin of Al phosphatesulphate minerals (woodhouseite and crandallite series) in terrestrial sandstones, Nova Scotia, Canada: American Mineralogist, v. 90, p. 1434-1441.

Preto, N., Kustatscher, E., And Wignall, P.B., 2010, Triassic climates: state of the art and perspectives: Palaeogeography, Palaeoclimatology, Palaeoecology, v. 290, p. 1-10.

Prokoph, A., Shields, G.A., AND VeIzer, J., 2008, Compilation and time-series analysis of a marine carbonate $\delta^{18} \mathrm{O}, \delta^{13} \mathrm{C},{ }^{87} \mathrm{Sr} /{ }^{86} \mathrm{Sr}$ and $\delta^{34} \mathrm{~S}$ database through Earth history: Earth-Science Reviews, v. 87, p. 113-133.
Retallack, G.J., Greaver, T., And Jahren, A.H., 2007, Return to Coalsack Bluff and the Permian-Triassic boundary in Antartica: Global and Planetary Change, v. 55, p. $90-108$.

Riccardi, A.L., Arthur, M.A., And Kump, L.R., 2006, Sulphur isotopic evidence for chemocline upward excursions during the end-Permian mass extinction: Geochimica et Cosmochimica Acta, v. 70, p. 5740-5752.

Robinson, B.W., and Bottrell, S.H., 1997, Discrimination of sulphate sources in pristine and polluted New Zealand river catchments using stable isotopes: Applied Geochemistry, v. 12, p. 305-319.

Royer, D.L., 2006, $\mathrm{CO}_{2}$-forced climate thresholds during the Phanerozoic: Geochimica et Cosmochimica Acta, v. 70, p. 5665-5675.

Rubidge, B.S., 1995, Biostratigraphy of the Beaufort Group (Karoo Supergroup) Geological Survey of South Africa, Biostratigraphic Series, v. 1, p. 1-46.

Smith, R., And Botha, J., 2005, The recovery of terrestrial vertebrate diversity in the South African Karoo Basin after the end-Permian extinction: Comptes Rendus Palévol, v. 4, p. 555-568.

Solé, R.V., Montoya, J.M., and ERwin, D.H., 2002, Recovery after mass extinction: Evolutionary assembly in large-scale biosphere dynamics: Royal Society of London, Philosophical Transactions, v. 357, p. 697-707.

SPÖTL, C., 1990, Authigenic aluminum phosphate-sulphates in sandstones of the Mitterberg Formation, Northern Calcareous Alps, Austria: Sedimentology, v. 37, p. 837-845.

Strauss, H., 1997, The isotopic composition of sedimentary sulphur through time: Palaeogeography, Palaeoclimatology, Plaeoecology, v. 132, p. 97-118.

TwitcheTt, R.J., 2006, The palaeoclimatology, palaeoecology and palaeoenviromental analysis of mass extinction events: Palaeogeography, Palaeoclimatology, Palaeoecology, v. 232, p. 190-213.

TwItcheTt, R.J., 2007, The Lilliput effect in the aftermath of the end-Permian extinction event: Palaeogeography, Palaeoclimatology, Palaeoecology, v. 252, p. 132-144.

Van Wees, J.D., Arche, A., Beiddorff, C.G., López-Gómez, J., and Cloetingh, S.A.P.L., 1998, Temporal and spatial variations in tectonic subsidence in the Iberian Basin (eastern Spain): inferences from automated forward modelling of high-resolution stratigraphy (Permian-Mesozoic): Tectonophysics, v. 300, p. 285 310 .

Vargas, H., Gaspar-Escribano, J., López-Gómez, J., Van Wees, J.D., Cloetingh, S. De la Horra, R., And Arche, A., 2009, A comparison of the Iberia and Ebro basins during the Permian and Triassic, eastern Spain: a quantitative subsidence modelling approach: Tectonophysics, v. 474, p. 160-183.

Wignall, P.B., AND Twitchett, R.J., 2002, Extent, duration and nature of the PermianTriassic superanoxic event, in Koeberl, C., and MacLeod, K.G., eds., Catastrophic Events and Mass Extinctions: Impacts and Beyond: Geological Society of America, Special Paper 356, p. 395-413.

Woods, A.D., 2005, Paleoceanographic and paleoclimatic context of Early Triassic time: Comptes Rendus Palévol, v. 4, p. 395-404.

Xie, S., Pancost, R.D., Wang, Y., Yang, H., Wignall, P.B., Lou, G., Jia, C., And Chen, L., 2010, Cyanobacterial blooms tied to volcanism during the 5 m.y. PermoTriassic biotic crisis: Geology, v. 38, p. 447-450.

Received 30 January 2012; accepted 5 February 2013. 